Alkın Kasaplar, H. ve Türkcan, K. (2021). "Yabancı Katma Değerin i̇hracat İçerisindeki Yerli Katma Değere Etkisi", Eskişehir Osmangazi Üniversitesi iiBF Dergisi, 16(3), 798 - 820.

Doi: 10.17153/oguiibf.947979

Başvuru: 05.06.2021 Kabul: 26.08.2021

Araştırma Makalesi/Research Article

\title{
Yabancı Katma Değerin İhracat İçerisindeki Yerli Katma Değere Etkisi ${ }^{1}$
}

\begin{tabular}{|c|c|}
\hline $\begin{array}{l}\text { Yabancı Katma Değerin İhracat İçerisindeki Yerli Katma } \\
\text { Değere Etkisi }\end{array}$ & $\begin{array}{l}\text { The Effect of the Foreign Value Added on the Domestic } \\
\text { Value Added in Exports }\end{array}$ \\
\hline Öz & Abstract \\
\hline $\begin{array}{l}\text { Küresel Değer Zinciri (KDZ), ticaret ve kalkınma } \\
\text { politikaları için önemli bir unsur olmasına rağmen } \\
\text { verilerin kısıtlı olması sebebiyle KDZ'nin iktisadi } \\
\text { performans üzerindeki etkisine dair çok az bilgi } \\
\text { bulunmaktadır. Bu çalışmada, Dünya Girdi-Çıktı Veri } \\
\text { Tabanı (WIOD) verileri kullanılarak yabancı katma değer } \\
\text { ile yerli katma değer arasındaki ilişki incelenmektedir. } \\
\text { Analiz, En Küçük Kareler Kukla Değişkeni (LSDV) yöntemi } \\
\text { aracılığıyla } 42 \text { ülke ve 2000-2014 dönemi için yapılmıştır. } \\
\text { Analiz bulguları, yabancı katma değerin, ileri katılım ve } \\
\text { yerli katma değer bağlamında ihracat performansını } \\
\text { artırdığını göstermektedir. }\end{array}$ & $\begin{array}{l}\text { Although Global Value Chains (GVCs) have become an } \\
\text { important topic for trade and development policy, little } \\
\text { is known about their impact on economic performance } \\
\text { because the data is limited. In this study, the relationship } \\
\text { between foreign value added and domestic value added } \\
\text { is analyzed using the World Input-Output Database } \\
\text { (WIOD) data. The analysis is conducted using the least } \\
\text { squares dummy variable (LSDV) approach for the period } \\
\text { of } 2000-2014 \text { of } 42 \text { countries. The findings show that } \\
\text { foreign value added enhances the export performance in } \\
\text { the context of forward linkage and domestic value } \\
\text { added. }\end{array}$ \\
\hline $\begin{array}{l}\text { Anahtar Kelimeler: Küresel Değer Zincirleri, Katma } \\
\text { Değer, Yerli Katma Değer, Yabancı Katma Değer, İhracat }\end{array}$ & $\begin{array}{l}\text { Keywords: Global Value Chains, Value Added, Domestic } \\
\text { Value Added, Foreign Value Added, Export }\end{array}$ \\
\hline JEL Kodları: F13, F14, F15, F63 & JEL Codes: F13, F14, F15, F63 \\
\hline
\end{tabular}

\begin{tabular}{|c|c|}
\hline $\begin{array}{l}\text { Araştırma } \\
\text { ve Yayın } \\
\text { Etiği Beyanı }\end{array}$ & Bu çalışma bilimsel araştırma ve yayın etiği kurallarına uygun olarak hazırlanmıştır. \\
\hline $\begin{array}{c}\text { Yazarların } \\
\text { Makaleye } \\
\text { Olan } \\
\text { Katkıları }\end{array}$ & Yazar 1'in makaleye katkısı \%50, Yazar 2'nin makaleye katkısı \%50'dir. \\
\hline Çıkar Beyanı & Yazarlar açısından ya da üçüncü taraflar açısından çalışmadan kaynaklı çıkar çatışması bulunmamaktadır. \\
\hline
\end{tabular}

\footnotetext{
${ }^{1}$ Bu çalışma, Akdeniz Üniversitesi Sosyal Bilimler Enstitüsü İktisat Anabilim Dalı’nda Prof. Dr. Kemal Türkcan danışmanlığında Huriye Alkın Kasaplar tarafından "Küresel Değer Zincirleri, İhracat, İstihdam ve Verimlilik" başlığı ile tamamlanarak 25.02.2021 tarihinde savunulan Doktora tezinden türetilmiştir.

${ }^{2}$ Arş. Gör. Dr., Akdeniz Üniversitesi, iïBF, iktisat, huriyealkin@akdeniz.edu.tr

${ }^{3}$ Prof. Dr., Akdeniz Üniversitesi, iiBF, iktisat, kturkcan@akdeniz.edu.tr
} 


\section{Giriş}

Uluslararası ticaret maliyetlerinin azalması ve iletişim teknolojisindeki gelişmeler sonucunda hem dış ticarette hem de sanayileşmede büyük bir dönüşüm gerçekleşmektedir (WTO, 2008; Amador ve Cabral, 2016; Baldwin ve Lopez-Gonzalez, 2015). Dış ticaret ve sanayileşmede gerçekleşen dönüşüm, ülkeler arasında daha fazla rekabet ve bağımlılık meydana getirmekte; ithal girdi kullanımını artırmaktadır. Günümüzde küresel ticaretin yaklaşık \%60'ını, ara mal ve hizmetler ticareti; ülkelerin gerçekleştirdikleri ihracatın dörtte birlik kısmını ise ithal girdi oluşturmaktadır (UNCTAD, 2013: 122; Baldwin, 2013; Dünya Kalkınma Raporu, 2020).

Bir ülke ya da firmanın küresel üretim sürecine katılımı, karşılaştırmalı üstünlük, nitelik ve kaynak donanımlarına bağı ılarak şekillenmektedir (Lopez-Gonzalez, 2016). İleri teknolojiye sahip gelişmiş ülkeler; Araştırma-Geliştirme (Ar-Ge), marka, tasarım ya da pazarlama gibi üretim aşamalarında uzmanlaşmaktadır. Düşük ücretli işgücü avantajına sahip olan gelişmekte olan ülkeler, üretim aşamasında ya da ürünün montaj aşamasında KDZ katılımı gerçekleştirmektedir (Degain vd., 2017). Katma değerden daha yüksek pay alan nitelikli işgücü, sermaye ve ileri teknolojiye sahip ülkeler ve katma değerden daha az pay alan düşük maliyetli emek gücüne sahip ülkelerin küresel üretim zincirine katılımları ile üretimde küreselleşme gerçekleşmektedir.

KDZ katılımında ülkeler, bir ürünün tüm üretim aşamalarını gerçekleştirmek yerine; üretimin belli bir aşamasında uzmanlaşmaktadır (Feenstra, 1998; Hummels vd., 2001). Firmaların ve ülkelerin dahil oldukları bu küresel üretim ve dağıtım ağı, KDZ olarak adlandırılmaktadır. KDZ katılımı, geri bağ ve/veya ileri bağ katılımı yolu ile gerçekleştirilmektedir. Geri bağ katılımı, ülkenin ihracatında ithal girdilerin kullanılması ile ilişkilidir. İleri bağ katılımı, ihraç edilen ara malının ticaret ortağı tarafından üçüncü ülkelere gerçekleştirilecek ihracatta kullanılmasını ifade etmektedir (Kummritz vd., 2017).

KDZ katılımı ile başta gelişmekte olan ülkelere olmak üzere; katılımcı tüm ülkelere rekabetçi fiyatlara sahip ara girdi, bilgi ve teknoloji akımı gerçekleşmektedir. Gelişmekte olan ülkeler, KDZ katılımı sonucunda rekabetçi fiyatlara sahip ara girdi ve bilgi temelli sermayenin temini ile rekabet düzeylerini artırabileceklerdir. Bilgi ve teknoloji akımı, eğitimli ve nitelikli emek talebini arttırarak işgücü piyasasında yapısal dönüşümün gerçekleşmesine katkıda bulunmaktadır. KDZ katılımı, gelişmekte olan ülkeler yanında; bilgi ve teknolojinin geliştirildiği gelişmiş ülkelerin de işgücü piyasasında dönüşümlere sebep olmaktadır (OECD, 2013; Taglioni ve Winkler, 2016; Kummritz, 2017).

Üretim ve dış ticarete farklı bir yön kazandıran üretim ayrıştırmasının yükselişi ile ülkelerin ithal girdi kullanımı arttığından; artan ithal girdinin ihracat performansı üzerinde nasıl bir etki yarattığının analiz edilmesi önem arz etmektedir. Verilerin kısıtlı olması sebebiyle litaratürde ithal girdi ile KDZ katıımı arasındaki ilişkinin analiz edildiği çalışmalar, az sayıdadır. Bu sebeple çalışmada, yabancı katma değerin ihracat performansı üzerindeki etkisi incelenmektedir. Analiz, WIOD verileri kullanılarak LSDV yöntemi aracılığıyla gelişmiş ve gelişmekte olan 42 ülke ve 2000-2014 dönemi için yapılmıştır. Beklentiler, ithal girdinin yurtiçinde yer alan ara malının ve teknolojinin tamamlayıcısı/ikamesi olması durumunda; üretimin, ihracat içerisindeki yerli katma değerin ve ileri katılımın artması/azalması yönündedir (Banga, 2016). Çalışmanın katkısı, KDZ katılımının gelişmiş ve gelişmekte olan ülkeler üzerindeki etki farklılığının incelendiği analizin sonuçlarına bağlı olarak KDZ katılımından elde edilen fayda düzeyinin artmasına yönelik ülke grubu bağlamında politika önerilerinde bulunmasıdır. Bu çalışma, ithal 
girdinin ihracat performansı üzerindeki etkisinin incelendiği diğer çalışmalardan, analizde yer alan ülke ve endüstrinin daha fazla olması ve analizin yapıldığı dönemin daha güncel olması bağlamında ayrışmaktadır. Çalışmada sırasıyla literatür, KDZ katılımı göstergeleri, ampirik analiz ve son bölümde de sonuç kısmı yer almaktadır.

\section{Literatür}

Gelişmiş ve gelişmekte olan ülkelerin üretim ve ticaret politikalarını etkileyen KDZ katılımı ile ilgili çalışmalar hızla artmaktadır. Bu çalışmalarda genel olarak KDZ katılımını hesaplamaya yönelik ayrıştırma yöntemleri geliştirilmekte, geliştirilen çeşitli yöntem ve veri tabanları kullanılarak ülkelerin KDZ katılımları hesaplanmaktadır. Ampirik çalışmalarda KDZ katılımının belirleyicilerinin incelenmesine odaklanılmaktadır. Literatürde KDZ katılımının, ülkelerin iktisadi performansı üzerindeki etkisi belirsizdir. Bu bağlamda çalışmada, ithal girdinin ihracat performansı üzerindeki etkisi incelenmektedir.

İthal girdinin, ihracat performansı üzerindeki etkisi; ihracat olasılığı, ihracat değeri, ihracat kapsamı gibi göstergeler bağlamında ölçülmektedir (Aristei vd., 2013; Turco ve Maggioni, 2013; Bas ve Strauss-Kahn, 2014; Pierola vd., 2015). Bas ve Strauss-Kahn (2014)'a göre, ithal girdi, farklı kanallar yoluyla ihracat performansını artırmaktadır. Dolaylı verimlilik kanalı bağlamında ithal girdinin verimliliği artırmasıyla firmalar, ihracatın sabit maliyetlerinin üstesinden gelebilmektedir. Doğrudan maliyet kanalına göre, düşük fiyatlı ithal girdi, rekabetçiliği ve beklenen ihracat gelirini artırabilecektir. Kalite/teknoloji kanalı ile ithal girdi, ihracat piyasasında kalite ve teknolojiyi temin edecek ve ihracatın sabit maliyetlerini azaltabilecektir.

İthal girdi, rekabetçilik ve ikame kanalı ile ihracat içerisindeki yerli katma değeri etkilemektedir. İthal girdinin, yurtiçinde yer alan ara malının ve teknolojinin tamamlayıcısı olması durumunda; üretimi, yerli katma değeri ve ileri katılımı artırması beklenmektedir. İthal girdinin, yurtiçinde yer alan ara malının ve teknolojinin ikamesi olması durumunda üretimi, yerli katma değeri ve ileri katılımı azaltması beklenmektedir. İkame etkisinin tamamlayıcı etkiden daha yüksek olması durumunda; endüstrideki üretim piyasası ve KDZ katılımı göstergeleri olumsuz etkilenecektir (Banga, 2016).

KDZ katılımı sonucunda gerçekleşen bilgi ve teknoloji yoğunluklu ithal girdinin temini, eğitimli ve nitelikli emek talebini artırarak işgücü piyasasında yapısal dönüşümün sağlanmasına katkıda bulunmaktadır. İşgücü piyasasındaki dönüşüm, ara malların yurtiçinde üretilmesini sağlayarak yerli katma değer artışını temin edebilecektir (Taglioni ve Winkler, 2016: 6-8; Kummritz, 2017: 7-8).

Kummritz (2015), Lopez-Gonzalez (2016) ve Solaz (2018)'ın çalışmaları, ithal girdinin katma değer üzerindeki etkisinin incelendiği çalışmalardandır. Kummritz (2015), analizini OECD’nin Ülkelerarası Girdi-Çıktı (ICIO) ve WIOD veri tabanını kullanarak 38 ülke ve 20 endüstri için gerçekleştirmiştir. 1995, 2000, 2005 ve 2008 yıllarını içeren analiz sonuçları, KDZ katılımından elde edilen fayda düzeyinin, ülkelerin gelişmişlik düzeyine bağlı olduğunu göstermektedir. İleri ve geri bağ KDZ katılımı, orta ve yüksek gelirli ülkelerin yerli katma değeri ile pozitif ilişkilidir. Gelişmiş ülkeler ileri katılımdan; orta gelir düzeyine sahip ülkeler ise geri bağ katılımından daha yüksek fayda sağlamaktadırlar. Düşük gelirli ülkeler ise KDZ katılımından fayda elde edememektedir. Lopez-Gonzalez (2016), yabancı katma değerin yerli katma değer üzerindeki etkisini, Asya ülkelerinin 1995, 2000, 2005, 2008, 2009, 2010, 2011 yıllarını kapsayan dönemi için analiz etmiştir. Analizin sonucuna göre, yabancı katma değer, yerli katma değeri belirleyen 
en önemli unsurdur. Yabancı katma değer, yerli katma değeri artırdığından ihracat için tamamlayıcı olma niteliği taşımaktadır. İspanya’nın 1995-2011 dönemindeki geri bağ katılımının yerli katma değer üzerindeki etkisini, WIOD veri tabanını kullanarak araştıran Solaz (2018), ithal girdi kullanımının yerli katma değeri artırdığı bulgusuna ulaşmıştır.

\section{KDZ Katılım Göstergeleri}

Bu çalışmada, ülkelerin endüstri seviyesindeki KDZ katılım göstergelerini hesaplamak için Wang vd. (2013) tarafından geliştirilen ayrıştırma yöntemi kullanılmaktadır. Wang vd. (2013) ayrıştırma yöntemi Leontief (1936) çalışmasına bağlı olarak geliştirilmiştir. Leontief ayrıştırma yönteminde, nihai mal ihracatı, yerli ve yabancı katma değer olarak ayrıştırılmaktadır. Wang vd. (2013), Leontief ayrıştırma yöntemini ara malın da ayrıştırılabildiği şekilde genişletmektedir. Wang vd. (2013)'in ayrıştırma yöntemine göre, üretilen mallar ya nihai mal ya da ara girdi olarak değerlendirilmektedir. Ülkeler, ara ve/veya nihai mal ve hizmetler ihracatı gerçekleştirmektedir. s ülkesinde üretilen mal, yurtiçinde veya yurtdışında ara veya nihai mal olarak tüketilmektedir.

Denklem (1)'de s ülkesinden $r$ ülkesine yapılan ihracat, 16 bileşen ve 8 kategori ile farklı katma değer ve çift sayılan bileşenlere ayrıştırılmaktadır. Katma değer ve çift sayılan bileşenlerin toplamı, endüstri düzeyinde yapılan ikili ihracatın toplamına eşittir.

$$
\begin{aligned}
E^{s r} & =\left(V^{s} B^{s s}\right)^{T} \# Y^{s r} \\
& +\left(V^{s} L^{s s}\right)^{T} \#\left(A^{s r} B^{r r} Y^{r r}\right) \\
& +\left(V^{s} L^{s s}\right)^{T} \#\left[A^{s r} \sum_{t \neq s, r}^{G} B^{r t} Y^{t t}+A^{s r} B^{r r} \sum_{t \neq s, r}^{G} Y^{r t}+A^{s r} \sum_{t \neq s, r}^{G} B^{r t} \sum_{u \neq s, t}^{G} Y^{t u}\right] \\
& +\left(V^{s} L^{s s}\right)^{T} \#\left[A^{s r} B^{r r} Y^{r s}+A^{s r} \sum_{t \neq s, r}^{G} B^{r t} Y^{t s}+A^{s r} B^{r s} Y^{s s}\right] \\
& \left.+\left[\left(V^{s} L^{s s}\right)^{T} \# A^{s r} B^{r s} \sum_{t \neq s}^{G} Y^{s t}\right)+\left(V^{s} L^{s s} \sum_{t \neq s}^{G} A^{s t} B^{t s}\right)^{T} \#\left(A^{s r} X^{r}\right)\right] \\
& +\left[\left(V^{r} B^{r s}\right)^{T} \# Y^{s r}+\left(\sum_{t \neq s, r}^{G} V^{t} B^{t s}\right)^{T} \# Y^{s r}\right] \\
& +\left[\left(V^{r} B^{r s}\right)^{T} \#\left(A^{s r} L^{r r} Y^{r r}\right)+\left(\sum_{t \neq s, r}^{G} V^{t} B^{t s}\right)^{T} \#\left(A^{s r} L^{r r} Y^{r r}\right)\right] \\
& +\left[\left(V^{r} B^{r s}\right)^{T} \#\left(A^{s r} L^{r r} E^{r^{*}}\right)+\left(\sum_{t \neq s, r}^{G} V^{t} B^{t s}\right)^{T} \#\left(A^{s r} L^{r r} E^{r^{*}}\right)\right]
\end{aligned}
$$

Denklemin ilk kategorisi, nihai mal ihracatındaki yerli katma değeri; ikinci ve üçüncü kategori, s ülkesinin $r$ ülkesine gerçekleştirdiği ara mal ihracatını göstermektedir. Üçüncü kategorideki ara mal, $r$ ülkesi tarafından s ülkesi dışında yer alan ülkelere ihracat yapmak üzere kullanılmaktadır. Üçüncü kategori, s ülkesinin ileri bağ katılımını; ilk üç kategorinin toplamı, s ülkesinin $r$ ülkesine gerçekleştirdiği ihracattaki yerli katma değeri göstermektedir. Dördüncü kategori, s ülkesi tarafından ihracatın gerçekleştirilmesinin ardından, s ülkesine geri dönen ara malı ihracatındaki yerli katma değeri göstermektedir. Beşinci kategori, yurtiçi çift sayım bileşenini; altıncı ve yedinci kategori, s ülkesinin $r$ ülkesine yaptığı ihracattaki yabancı katma değerin toplamını; sekizinci kategori, s ülkesinin ihracatında çift sayılmış olan yabancı katma değeri göstermektedir. 


\subsection{Seçilmiş Ülkelere Ait İkili Ticaret-Endüstri Düzeyinde KDZ Göstergeleri}

Çalışmada yer alan 42 ülkeden seçilen gelişmiş ve gelişmekte olan ${ }^{4}$ bir grup ülkenin ${ }^{5}$ Wang vd. (2013)'in geliştirdiği ayrıştırma yöntemi kullanılarak hesaplanan ihracat içerisindeki yerli katma değer, ileri katılım ve yabancı katma değer oranları betimsel olarak gösterilmektedir. Grafik 1 ve Grafik 2'de, söz konusu bu ülkelerin 2000 ve 2014 yıllarına ait imalat sanayi ve hizmetler endüstrisi yerli katma değer oranları gösterilmektedir.

Grafik 1: Gelişmiş Ülkelerin Yerli Katma Değer Oranı

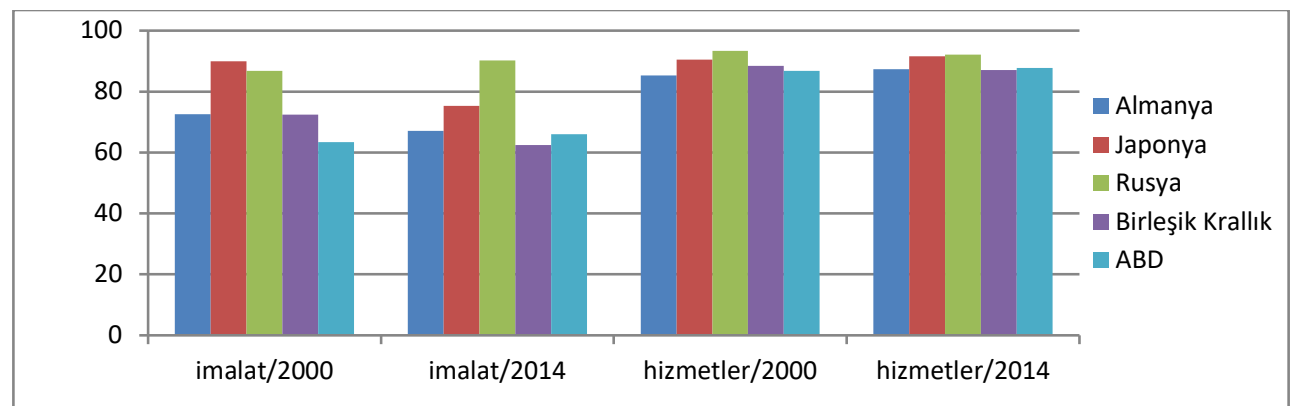

Kaynak: WIOD verileri kullanılarak yazarlar tarafından hesaplanmıştır.

Grafik 2: Gelişmekte Olan Ülkelerin Yerli Katma Değer Oranı

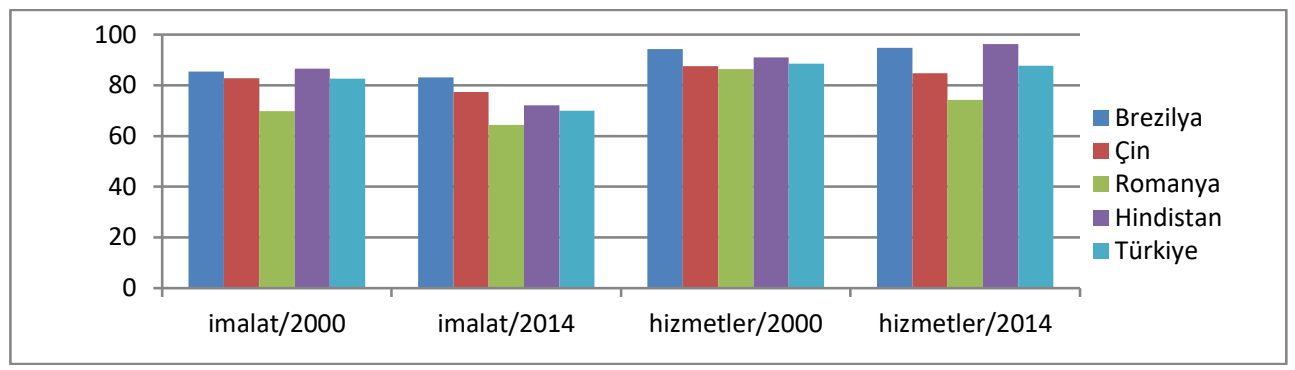

Kaynak: WIOD verileri kullanılarak yazarlar tarafından hesaplanmıştır.

Grafik 1'de görüldüğü üzere, gelişmiş ülkelerde yerli katma değer oranı en düşük olan endüstri, imalat sanayidir. 2000-2014 döneminde, özellikle imalat sanayi endüstrisinin yerli katma değer oranlarında azalış gerçekleşmiştir. 2014 yılında, imalat sanayi endüstrisi en düşük yerli katma değer oranına sahip olan ülkeler, Birleşik Krallık ve ABD'dir. Rusya ve Japonya'nın imalat sanayi endüstrisindeki yerli katma değer oranı, diğer ülkelere göre daha yüksektir. Yerli katma değer oranı imalat sanayiye göre daha yüksek olan hizmetler endüstrisinde, yerli katma değer oranı en yüksek olan ülkeler sırasıyla Rusya ve Japonya'dır.

Grafik 2'ye göre, gelişmiş ülkelerde olduğu gibi, yerli katma değer oranı, 2014 yılında daha düşük gerçekleşmiştir. Benzer bir diğer bulguya göre, imalat sanayi endüstrisinde yerli katma değer oranı; hizmetler endüstrisi yerli katma değer oranından daha düşüktür. 2014 yılında

4 Gelir düzeyi ayrıştırması, Dünya Bankası Gayrisafi Milli Hasıla (GSMH) 2018 verileri kullanılarak gerçekleştirilmektedir. Ülkelerin gelir düzeyi ayrıştırması, EK 1'de yer almaktadır.

${ }^{5}$ Almanya, Japonya, Rusya, Birleşik Krallık ve Amerika, gelişmiş ülke grubunu; Brezilya, Çin, Romanya, Hindistan ve Türkiye, gelişmekte olan ülke grubunu temsil etmektedir. 
imalat sanayi endüstrisinde en yüksek yerli katma değer oranının elde edildiği ülkeler, Brezilya ve Çin'dir. Hizmetler endüstrisinde en yüksek yerli katma değer oranına sahip ülkeler sırasıyla Hindistan ve Brezilya'dır.

Grafik 3 ve Grafik 4'te söz konusu ülkelerin ileri katılım oranları gösterilmektedir. Grafik 3'te gelişmiş ülkelerin ileri katılım oranlarının 2000-2014 yılları arasında arttığı görülmektedir. İmalat sanayi endüstrisinde ileri katılım oranı; hizmetler endüstrisine göre daha düşük oranda gerçekleşmektedir. 2014 yılında imalat sanayi ileri katılım oranı en yüksek olan ülkeler, Rusya ve Birleşik Kralıı; hizmetler endüstrisi ileri katılım oranı en yüksek olan ülkeler sırasıyla $A B D$ ve Birleşik Krallık'tır.

Grafik 3: Gelişmiş Ülkelerin İleri Katılım Oranı

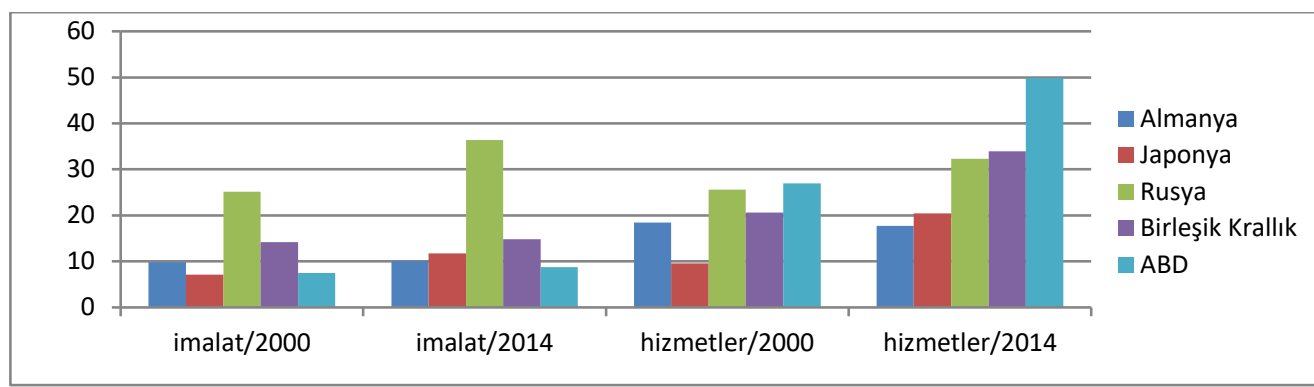

Kaynak: WIOD verileri kullanılarak yazarlar tarafından hesaplanmıştır.

Grafik 4: Gelişmekte Olan Ülkelerin İleri Katılım Oranı

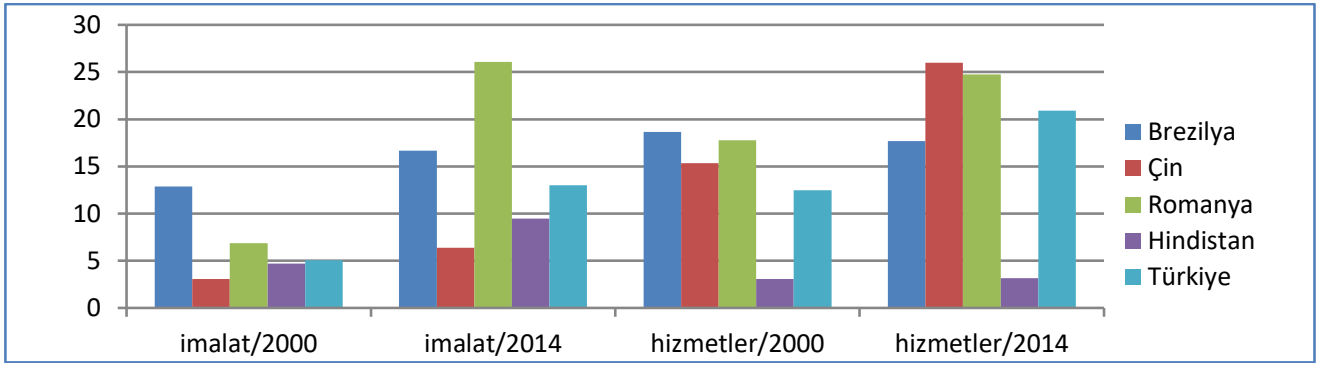

Kaynak: WIOD verileri kullanılarak yazarlar tarafından hesaplanmıştır.

Grafik 4'te görüldüğü üzere, 2014 yılında ileri katılım oranı, gelişmiş ülkelerde olduğu gibi genel olarak daha yüksek seviyelerde gerçekleşmiştir. Hizmetler endüstrisine ait ileri katılım oranı, imalat sanayi endüstrisine ait ileri katılım oranından daha yüksektir. 2014 yılında imalat sanayi ileri katılım oranı en yüksek olan ülke, Romanya'dır. Hizmetler endüstrisinde en yüksek ileri katılım oranı Çin'e aittir.

Gelişmiş ve gelişmekte olan ülkelerin yabancı katma değer oranları, Grafik 5 ve Grafik 6'da gösterilmektedir. Grafik 5'e göre, imalat sanayi endüstrisinde yabancı katma değer oranı, 2014 yılında daha yüksek gerçekleşmiştir. İmalat sanayide yabancı katma değer oranı, hizmetler endüstrisine göre daha yüksektir. 2014 yılında imalat sanayi ve hizmetler endüstrisinde en yüksek yabancı katma değer oranı sırasıyla Birleşik Krallık ve Almanya'ya aittir. Grafik 6'ya göre, gelişmiş ülkelerde olduğu gibi, imalat sanayide yabancı katma değer oranı, hizmetler endüstrisinden daha yüksektir. İmalat sanayi endüstrisinde yabancı katma 
değer oranı, 2014 yılında daha yüksektir. 2014 yılında imalat sanayi yabancı katma değer oranı en yüksek olan ülke, Türkiye'dir. Hizmetler endüstrisinde 2014 yılı yabancı katma değer oranı, ülkelerin birçoğunda daha düşük gerçekleşmiştir. Diğer gelişmekte olan dört ülkeden farklı olarak, Romanya'nın 2014 yılında hizmetler endüstrisi yabancı katma değer oranı artmıştır.

Grafik 5: Gelişmiş Ülkelerin Yabancı Katma Değer Oranı

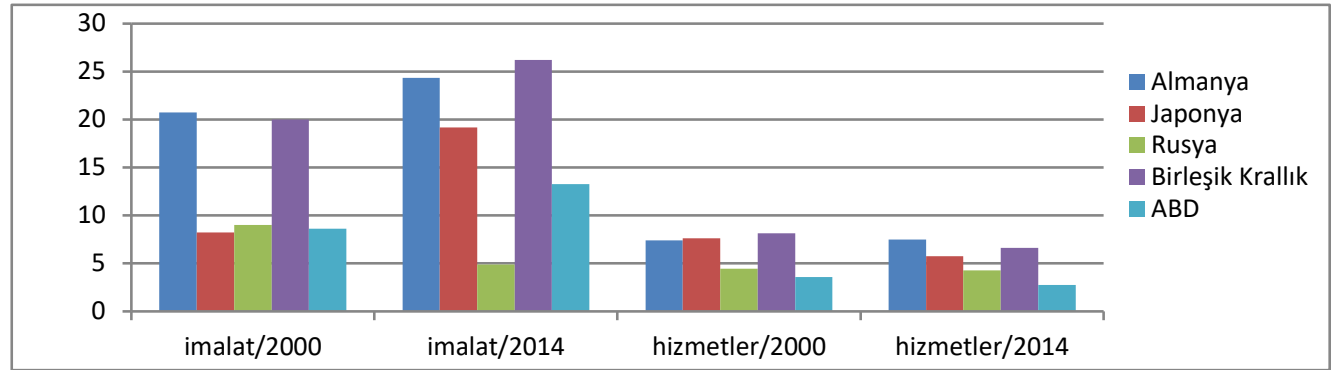

Kaynak: WIOD verileri kullanılarak yazarlar tarafından hesaplanmıştır.

Grafik 6: Gelişmekte Olan Ülkelerin Yabancı Katma Değer Oranı

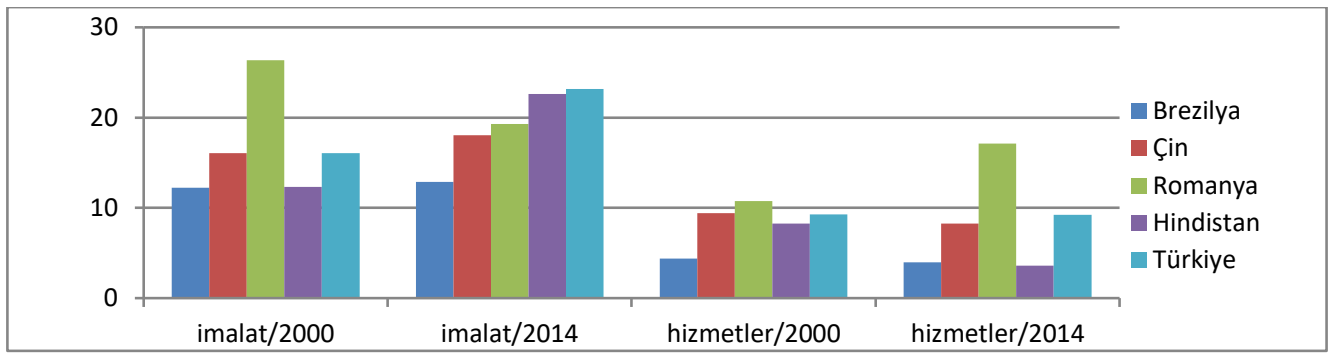

Kaynak: WIOD verileri kullanılarak yazarlar tarafından hesaplanmıştır.

Gelişmiş ve gelişmekte olan ülkelerin sonuçları özetlenecek olursa; imalat sanayi ve hizmetler endüstrisine ait yerli katma değer oranı, seçilmiş gelişmiş ve gelişmekte olan ülkelerde benzer seviyelerde gerçekleşmiştir. Ülkelerin genelinde yerli katma değer oranı, 2014 yılında daha düşüktür. Gelişmiş ve gelişmekte olan ülkelerin ileri katılım oranı, 2014 yılında yükselmiştir. İmalat sanayi ve hizmetler endüstrisinde, 2014 yılı ileri katılım oranı daha yüksek olan ülke grubu, gelişmiş ülkelerdir. Vurgulanması gereken bir başka bulgu, yabancı katma değer oranının 2014 yılında daha yüksek olduğudur. İmalat sanayi ve hizmetler endüstrisine ait yabancı katma değer oranı, gelişmiş ülkelerde daha düşüktür. 


\section{Ampirik Analiz}

Çalışmada 42 ülkenin, 2000-2014 döneminde endüstri düzeyinde gerçekleştirdiği ihracattaki yabancı katma değerin, yerli katma değer ve ileri bağ katılımı üzerindeki etkisi analiz edilmektedir. Analizde çekim modeli ${ }^{6}$ kullanılmaktadır. Modelin oluşturulmasında Kowalski vd. (2015:23) ve Kummritz (2015)'in analizlerinde yer alan modellerden faydanılmaktadır.

$$
\mathrm{LKDZ}_{\mathrm{ijst}}=\alpha+\beta_{1} \mathrm{LYAB}_{\mathrm{ijst}-1}+\beta_{2} \mathrm{LKD}_{\mathrm{it}}+\alpha_{\mathrm{ijst}}
$$

Bağımlı değişken olan $\mathrm{LKDZ}_{\mathrm{ijst}}$ ihracat içerisindeki yerli katma değer ve ileri bağ katılım değerini; modelde etkisi incelenen temel değişken olan $L_{Y A B}{ }_{i j s t-1}$, ihracat içerisindeki yabancı katma değeri; $\mathrm{LKD}_{\text {it }}$ kontrol değişkenleri; i, ihracat yapan ülkeyi; j, ihracatçı ülkenin ticaret ortağını; s, endüstriyi ve $t$, yılı göstermektedir. Kontrol değişkenleri olarak çekim modeli değişkenlerinden olan GSYiH, uzaklık ve ticaret maliyetleri yanında; ülke düzeyinde beşeri sermaye, patent başvuruları, ticaret anlaşmaları; endüstri düzeyinde sermaye kullanılmaktadır.

Analiz 42 ülke, $54^{7}$ endüstri ve 2000-2014 dönemi için gerçekleştirilmektedir. Analizde kullanılan ilk model, Denklem (3)'te yer almaktadır.

$$
\begin{aligned}
\text { LYKD }_{i j s t} & =\alpha+\beta_{1} \text { LYAB }_{i j s t-1}+\beta_{2} \text { LGSYIH }_{i t}+\beta_{3} \text { LGSYIH }_{j t}+\beta_{4} \text { LUZAK }_{i j}+\beta_{5} \text { LBS }_{i t} \\
& +\beta_{6} \text { LS }_{i s t}+\beta_{7} \text { BTA }_{i j t}+\beta_{8} \text { LTM }_{i j t}+\beta_{9} \text { LGS }_{i t}+\beta_{10} \text { LP }_{i t}+\alpha_{i}+\alpha_{j}+\alpha_{\mathrm{s}}+\alpha_{z}+\alpha_{i j s t}
\end{aligned}
$$

Denklem (3)'te yer alan $\mathrm{LYKD}_{\mathrm{ijst}}$, ihracat içerisindeki yerli katma değeri; $\mathrm{LYAB}_{\mathrm{ijst}-1}$, ihracat içerisindeki yabancı katma değeri; $\mathrm{LGSYIH}_{\mathrm{it}}$, ihracat yapan ülkenin gayrisafi yurtiçi hasılasını; $\mathrm{LGSYIH}_{\mathrm{jt}}$, ticaret ortağının gayrisafi yurtiçi hasılasını göstermektedir. $\mathrm{LUZAK}_{\mathrm{ij}}$, ihracat yapan ülke ile ticaret ortağı ülkenin başkentleri arasındaki km cinsinden uzaklığı; $\mathrm{LBS}_{\text {it, }}$, beşeri sermayeyi; $\mathrm{LS}_{\mathrm{ist}}$, çalışan başına sermaye stoğunu; $\mathrm{BTA}_{\mathrm{ijt}}$, ihracatçı ülke ile ticaret ortağı ülke arasında, bölgesel ticaret anlaşmasının var olup olmadığını gösteren kukla değişkeni; $\mathrm{LTM}_{\mathrm{ijt}}$, ticaret maliyetlerini; $\mathrm{LGS}_{\mathrm{it}}$, gelen doğrudan yabancı sermaye akımını; $\mathrm{P}_{\mathrm{it}}$, toplam patent başvurularını ifade etmektedir.

$\mathrm{LGSYİH}_{\text {it }}$ ve LGSYİH ${ }_{\mathrm{jt}}$, piyasa büyüklüğü göstergesidir. $\mathrm{LUZAK}_{\mathrm{ij}}$, ulaşım maliyetlerinin temsilcisidir (proxy). Beşerî sermaye temsilcisi olarak modele dahil edilen $\mathrm{LBS}_{\text {it }}, 15$ yaş ve üzeri bireylerde ortalama okullaşma oranını göstermektedir. Toplam patent başvurularını ifade eden $\mathrm{LP}_{\text {it }}$, teknolojik ilerleme ve yeniliğin bir temcilcisi olarak modele dahil edilmektedir. Modelde yer alan çalışan başına sermaye $\left(\mathrm{LS}_{\text {ist }}\right)$, sermaye ödemesinin işgücü ödemesine bölünmesi ile elde edilmektedir.

Denklem (4)'te yer alan modelde, ileri bağ katılımı göstergesinin belirleyicileri sunulmaktadır. LIBKK $_{\mathrm{ijst}}$, ihracatçı ülke olan i ülkesinden ticaret ortağı olan j ülkesine, $\mathrm{s}$ endüstrisinde $t$ zamanında yapılan ileri bağ katılım değerini göstermektedir. Modellerde yer alan $\alpha_{\mathrm{i}}$ ve $\alpha_{\mathrm{j}}$, i ve j ülkesi kukla değişkenlerini; $\alpha_{\mathrm{s}}$ ve $\alpha_{\mathrm{t}}$, endüstri ve yıl kukla değişkenlerini;

\footnotetext{
${ }^{6}$ Çekim modeli; iki ülke arasındaki uzaklık, kullanılan dil, para birimi, gelir gibi değişkenlere bağlı olarak ikili ticareti analiz etmekte yaygın bir şekilde kullanılmaktadır.

${ }^{7}$ WIOD, endüstrilerin Tüm Ekonomik Faaliyetlerin Uluslararası Standart Sanayi Sınıflaması'na (ISIC, Rev. 4) bağlı olarak sınıflandırıldığı bir veri tabanıdır. WIOD veri tabanında yer alan 56 endüstriden, hanehalkının kendi kullanımı için gerçekleştirdiği farklılaştırılmamış mal ve hizmet üretiminin ve sınırötesi organizasyonlar ve kurumların yer aldığı 55 . ve 56. endüstriler analize dahil edilmemiştir.
} 
$\alpha_{i j s t}$ ise hata terimini temsil etmektedir. $L_{Y K D_{i j s t}}, L_{I B K} K_{i j s t}, L Y A B_{i j s t}, L S_{i s t}$ değişkenleri WIOD veri tabanının Sosyo-Ekonomik Hesaplarında yer alan endüstri düzeyinde GSYiH deflatörü kullanılarak; $\mathrm{LGSYIH}_{i t}, \mathrm{LGSYIH}_{\mathrm{jt}}, \mathrm{LGS}_{\mathrm{it}}$ değişkenleri tüketici fiyat endeksi kullanılarak reel hale dönüştürülmektedir. Kukla değişkenleri dışındaki değişkenler logaritmaları alınarak modele dahil edilmektedir.

$$
\begin{aligned}
\text { L̇BK }_{i j s t}= & \alpha+\beta_{1} \text { LYAB }_{i j s t-1}+\beta_{2} \text { LGSYİH }_{i t}+\beta_{3} \text { LGSYIH }_{j t}+\beta_{4} \text { LUZAK }_{i j}+\beta_{5} \text { LBS }_{i t} \\
& +\beta_{6} \text { LS }_{i s t}+\beta_{7} \text { BTA }_{i j t}+\beta_{8} \text { LTM }_{i j t}+\beta_{9} L_{G} S_{i t}+\beta_{10} \mathrm{LP}_{i t}+\alpha_{i}+\alpha_{j}+\alpha_{s}+\alpha_{z}+\alpha_{i j s t}
\end{aligned}
$$

\subsection{Veri}

Denklemlerde yer alan yerli katma değer, ileri katılım ve yabancı katma değer, Wang vd. (2013) tarafından geliştirilen ayrıştırma yöntemi kullanılarak ${ }^{8}$ hesaplanmaktadır. Yerli katma değer, ayrıştırma metodunda yer alan 16 bileşenden ilk beşinin; ileri katılım, 3, 4 ve 5 numaralı bileşenlerin ve yabancı katma değer, 11, 12, 13 ve 14 numaralı bileşenlerin toplanmasıyla elde edilmektedir.

Denklem (3) ve (4)'teki modellerde yer alan yerli katma değer $\left(\mathrm{LYKD}_{\mathrm{ijst}}\right)$, ileri bağ katılımı $\left(\mathrm{LIBK}_{\mathrm{ijst}}\right)$ ve yabancı katma değer $\left(\mathrm{LYAB}_{\mathrm{ijst}}\right)$, WIOD veri tabanının 2016 revizyonlu versiyonu kullanılarak hesaplanmaktadır. GSYiH değişkenleri, Dünya Banka'sına ait Dünya Kalkınma Göstergeleri'nden (World Development Indicators); uzaklık değişkeni ( $L_{U Z A K}{ }_{i j}$ ) CEPII'ye (Centre d'Etudes Prospectives et d'Informations Internationales) ait veri tabanından; beşeri sermaye $\left(\mathrm{LBS}_{\mathrm{it}}\right)$ temsilcisi olarak kullanılan okullaşma oranı, Penn World Table veri tabanından; çalışan başına sermaye stoku $\left(\mathrm{LS}_{\mathrm{it}}\right)$, WIOD veri tabanının Sosyo-Ekonomik Hesaplarından; bölgesel ticaret anlaşmaları $\left(\mathrm{BTA}_{\mathrm{ijt}}\right.$ ), Dünya Ticaret Örgütü (WTO) ve Jeffry Bergstrand'a ait veri tabanından; ticaret maliyetleri $\left(\mathrm{LTM}_{\mathrm{ijt}}\right)$ Dünya Bankası Ticaret Maliyetleri veri tabanından; gelen doğrudan yabancı sermaye yatırımları ( $\mathrm{LGS}_{\text {it }}$ ) Dünya Bankası'na ait veri tabanından; toplam patent sayısı $\left(\mathrm{LP}_{\mathrm{it}}\right), \mathrm{OECD}$ veri tabanından temin edilmektedir ${ }^{9}$.

İthal girdinin yurtiçinde yer alan ara malının ve teknolojinin tamamlayıcısı/ikamesi olması durumunda; üretimin, yerli katma değerin ve ileri katılımın artması/azalması beklenmektedir. İkame etkisinin tamamlayıcı etkiden daha yüksek olması durumunda; endüstrideki üretim piyasası ve KDZ katılımı göstergeleri olumsuz etkilenecektir (Banga, 2016).

Çekim modeli teorisine göre ticaret hacmi, ticaret ortaklarının ekonomi büyüklüğü ile pozitif; ülkeler arasındaki uzaklık ve ticaret maliyetleri ile negatif ilişkilidir (Anderson, 1979; Evenett ve Keller, 2002; Anderson ve van Wincoop, 2003). Illeri ve geri endüstri bağı bağlamında KDZ katılımı ile piyasa büyüklüğü arasında pozitif bir ilişki yerine; daha karmaşık bir ilişki bulunmaktadır. Büyük piyasaya sahip ülkeler, gerçekleştirdikleri üretim için ara malını yurtiçinde temin etmekte ve daha düşük oranda ithal girdiye gereksinim duymaktadır. Kowalski vd. (2015)'ye göre, piyasa büyüklüğü ile ileri bağ katılım arasında pozitif bir ilişki bulunmaktadır. Piyasa büyüklüğü arttıkça bu ülkelerin ara girdilerinin diğer ülkelerin ihracatlarında kullanılma oranı artmaktadır. Uluslararası ticaretin önemli belirleyicilerinden olan uzaklık arttıkça ülkelerin ya da firmaların, yabancı piyasada mal ve hizmet faaliyetlerinde bulunması daha maliyetli olacaktır. Uzaklığın, KDZ katılımında da benzer sonuçlar doğuracağı beklenmektedir (Kowalski vd, 2015). Dolayısıyla uzaklık; ülkeleri ya da firmaları, maliyet

\footnotetext{
${ }^{8}$ Göstergelerin hesaplanmasında Stata12 ve R programı kullanılmıştır.

${ }^{9}$ Değişkenlere ait tanımlayıcı istatistikler, Ek 2'de yer almaktadır.
} 
azaltıcı etki yaratan ucuz ithal girdi kullanımına yönelteceğinden beklentiler, yerli katma değerin ve ileri bağ katılımın azalacağı yönündedir.

Eğitim ve nitelik, beşerî sermayenin KDZ katılımını artırmada önem arz etmektedir (Farole ve Winkler, 2014). Eğitim aracılığıyla beşerî sermayenin artırılması; işgücünün daha nitelikli ve verimli olmasını sağlayarak yazılım, veri tabanı gibi bilgi temelli sermayenin ve patent gibi yenilikçi varlıkların üretilmesini olanaklı kılmaktadır (OECD, 2013: 22-50). Beşerî sermaye $\left(L_{\text {it }}\right.$ ) gibi işgücü başına sermaye artışı da ( $L S_{i t}$ ) işgücü verimliliğini artırarak firmaların yenilikçi kapasitelerinin artışına ve teknoloji yoğunluklu üretim yapmasına katkıda bulunabilecektir. Üretimde yüksek teknolojiyi kullanma kabiliyetine sahip nitelikli işgücü, ara girdilerin yurt içinde üretilmesini sağlayabilecek ve rekabetçiliği artırabilecektir. Bu sebeple, beklentiler, beşerî sermayenin $\left(\mathrm{LBS}_{\mathrm{it}}\right)$ ve işgücü başına sermaye $\left(\mathrm{LS}_{\mathrm{it}}\right)$ artışının, yerli katma değeri ve ileri katılımı artıracağı yönündedir.

Bölgesel ticaret anlaşmalarının $\left(\mathrm{BTA}_{\mathrm{ijt}}\right)$, artan ticaretin sonucunda mı yapıldığı yoksa ticaretin artması için mi ticaret anlaşmalarının yapıldığı literatürde tartışmalı bir konudur. Dolayısıyla her ne kadar ticaret politikaları KDZ katılımı için önem arz etse de ticaret anlaşmalarının yeni değer zinciri yaratıp yaratmadığı hususu henüz netlik kazanmış değildir (Kowalski vd., 2015).

Ticaret maliyetlerindeki $\left(\mathrm{LTM}_{\mathrm{ijt}}\right)$ artış, ülkeleri ya da firmaları alıcı-satıcı ilişkisine yatırım yapmadan; rekabetçiliği artırmak için maliyet azaltıcı faaliyetlere yöneltecektir. Rekabet düzeyinin artması için firmalar, ucuz ithal girdi kullanımına başvuracaktır (Heise vd., 2017). Bu sebeple, ticaret maliyetlerindeki artışın, yerli katma değeri ve ileri bağ katılımını düşürmesi beklenmektedir.

Gelen doğrudan yabancı sermaye yatırımı $\left(L_{G S}\right.$ it), ileri ve geri bağ KDZ katılımı ile yakından ilişkilidir. Sermayeye ihtiyaç duyulan ülkelerde yapılan doğrudan yabancı sermaye yatırımı, bu ülkelerin yerli katma değeri ve ileri bağ katılımını artırmalarına olanak sağlayacaktır. Yatırımların, yatırım yapılan ülkede ihracat yapılması amacıyla ithal girdi temini sağlaması durumunda; ülkenin geri bağ katılımını da benzer şekilde artırması beklenmektedir (bkz: Hummels, 2001; Miroudot vd., 2009; Kowalski vd., 2015).

KDZ'ye katılımda en yüksek katma değer, Ar-Ge gibi üretime dönük aşamalarda gerçekleşmektedir (OECD, 2013). Ar-Ge alanlarında yatırımı göreceli olarak fazla olan ülkeler, üretimde yüksek teknoloji kullanma kabiliyeti gerektiren, rekabeti yüksek olan yüksek katma değerli faaliyetlerde bulunabileceklerdir. Bu sebeple Ar-Ge harcamalarına temsilci olarak kullanılan patent başvuru sayısındaki $\left(\mathrm{LP}_{\mathrm{it}}\right)$ artışın, yerli katma değeri ve ileri katılımı artırması beklenmektedir. 


\subsection{Uygulama}

KDZ göstergeleri değer olarak modele dahil edilmektedir. Analizde yer alan modellerin tümü, sabit etkili en küçük kareler ${ }^{10}$ olarak da nitelendirilen LSDV yöntemi ile tahmin edilmektedir. KDZ belirleyicilerini etkileyebilecek coğrafi konum ya da teknoloji farklılıkları gibi zaman içerisinde değişmeyen, ülkeye özgü özellikleri kontrol edebilmek amacıyla Kowalski vd. (2015)'nin çalışmasından faydalanılarak modele ülke kukla değişkeni eklenmektedir. Ziemann ve Guerard (2016)'ın çalışması takip edilerek yıl kukla değişkeni modele dahil edilmektedir. Gözlenemeyen endüstriye özgü özellikler için endüstri kukla değişkeni eklenmektedir. Modellerde yer alan standart hatalar, ülke ve endüstriye bağlı olarak kümelenmiş dirençli standart hatalardır. Dirençli standart hata, $n$ büyük; $t$ küçük iken otokorelasyon ve değişen varyanslılık durumlarında da kullanılabildiği için tercih edilmektedir ${ }^{11}$. İçsellik probleminin önüne geçebilmek için Ebenstein vd. (2014)'in çalışması takip edilerek yabancı katma değerin bir gecikmeli değeri alınarak modele eklenmektedir.

\subsection{Ampirik Analiz Sonuçları}

Yabancı katma değerin yerli katma değer ve ileri katılım üzerindeki etkisinin incelendiği analizde, 42 ülke ve 54 endüstrinin yer aldığı temel model, gelişmiş ve gelişmekte olan ülkelere ait temel model ve endüstri düzeyinde modeller oluşturulmaktadır. Ülke düzeyindeki modeller; ülkelerin, gelir düzeylerine ${ }^{12}$ bağlı olarak gelişmiş ve gelişmekte olan ülke gruplarına ayrılmasıyla kurulmaktadır. Endüstri düzeyindeki modeller; 54 endüstrinin, $\operatorname{tarım}^{13}$, madencilik, imalat sanayi ve hizmetler endüstrisi olacak şekilde toplulaştırılmasıyla oluşturulmaktadır.

\subsubsection{Yabancı Katma Değerin Yerli Katma Değer Üzerindeki Etkisi}

Tablo 1'de temel model ve ülke ve endüstri düzeyindeki model sonuçları yer almaktadır. Tüm örneklem ve ülke ve endüstri düzeyinde gerçekleştirilen analiz sonuçlarına göre yabancı katma değer $\left(\mathrm{LYAB}_{\mathrm{ijst}-1}\right)$ ile yerli katma değer $\left(\mathrm{LYKD}_{\mathrm{ijst}}\right)$ arasında istatistiksel olarak anlamlı ve pozitif bir ilişki bulunmaktadır. Endüstri düzeyinde gerçekleştirilen model sonuçlarına göre, yabancı katma değerin $\left(\mathrm{LYAB}_{\mathrm{ijst}-1}\right)$ yerli katma değer $\left(\mathrm{LYKD}_{\mathrm{ijst}}\right)$ üzerindeki etkisinin en yüksek olduğu endüstri, hizmetlerdir.

Ithal girdi, firmaların kaliteli ve ucuz girdi temin ederek maliyetlerini azaltmalarını ve rekabet düzeylerini artırmalarını sağlamaktadır. İthal girdi ile yurtiçine verimli kaynak, bilgi ve teknoloji akımı gerçekleşmektedir. Gelişmiş teknoloji, beşerî sermayesi güçlü çalışan ihtiyacını artıracağından işgücü piyasasında iyileşmenin sağlanmasına katkıda bulunacaktır. İşgücü piyasasında iyileşme ile yurtdışından temin edilen girdiler, yurtiçinde üretilebilecektir. Dolayısıyla ithal girdi, yurtiçinde yer alan ara malın ve teknolojinin tamamlayıcısı olma özelliği ile ihracat için de tamamlayıcı bir nitelik taşımaktadır. Elde edilen bu sonuç, tarım, madencilik, imalat sanayi ve hizmetler endüstrisinden oluşan dört ana endüstri için geçerlidir. Ithal girdinin, yurtiçindeki ara malın ve teknolojinin tamamlayıcısı/ikamesi olma özelliği alt endüstrilerde değişkenlik gösterebilecektir. Ulaşılan sonuca benzer şekilde; Kummritz $(2015 ; 2016)$, Lopez-Gonzalez (2016) ve Solaz (2018), ithal girdi kullanımının, yerli katma değerin tamamlayıcısı olduğu ve KDZ katılımının, yurtiçi piyasayı olumlu etkilediğini tespit

\footnotetext{
${ }^{10}$ Bknz: Baltagi (2008: 14-17)

${ }^{11}$ Yerli katma değer ve ileri bağ katılım belirleyicileri analizine ait çoklu bağlantı test sonuçları, Ek 3'te yer almaktadır.

12 Gelir düzeyi ayrıştırması, Dünya Bankası GSMH (2018) verileri kullanılarak gerçekleştirilmektedir.

${ }^{13}$ Ormancılık ve balıkçılık endüstrileri, tarım endüstrisi sınıflandırması içerisinde yer almaktadır.
} 
etmiştir. ihracat performansının, ithalatla ilintili olduğu sonucunu destekleyen bir diğer çalışma, Assamoi vd. (2019)'nin çalışmasıdır. Assamoi vd. (2019)'nin Latin Amerika ülkelerinin, yerli katma değer belirleyicilerini araştırdıkları çalışmalarının sonucuna göre, yabancı katma değer yerli katma değerin önemli bir belirleyicisidir.

Tablo 1: Yabancı Katma Değerin Yerli Katma Değer Üzerindeki Etkisi

\begin{tabular}{|c|c|c|c|c|c|c|c|}
\hline & $\begin{array}{l}\text { Temel } \\
\text { Model }\end{array}$ & $\begin{array}{l}\text { Gelişmiş } \\
\text { Ülke }\end{array}$ & $\begin{array}{l}\text { Gelişmekte } \\
\text { Olan Ülke }\end{array}$ & Tarım & Madencilik & $\begin{array}{l}\text { İmalat } \\
\text { Sanayi }\end{array}$ & Hizmetler \\
\hline \multirow[t]{2}{*}{ LYAB $_{i j s t-1}$} & $0,896^{* * *}$ & $0,886^{* * *}$ & $0,909^{* * *}$ & $0,819^{* * *}$ & $0,772^{* * *}$ & $0,809^{* * *}$ & $0,915^{* * *}$ \\
\hline & $(0,001)$ & $(0,001)$ & $(0,003)$ & $(0,005)$ & $(0,012)$ & $(0,003)$ & $(0,002)$ \\
\hline \multirow[t]{2}{*}{ LGSYİH $_{\text {it }}$} & 0,019 & $-0,067^{* * *}$ & $-0,295^{* * *}$ & $-0,079$ & 0,049 & $0,058^{* * *}$ & $-0,022$ \\
\hline & $(0,015)$ & $(0,019)$ & $(0,049)$ & $(0,073)$ & $(0,115)$ & $(0,021)$ & $(0,021)$ \\
\hline \multirow[t]{2}{*}{ LGSYİH $_{\mathrm{jt}}$} & $0,075^{* * *}$ & $0,101^{* * *}$ & 0,019 & $0,312^{* * *}$ & $0,289^{* * *}$ & $0,191^{* * *}$ & $0,049^{* * *}$ \\
\hline & $(0,011)$ & $(0,012)$ & $(0,026)$ & $(0,060)$ & $(0,110)$ & $(0,017)$ & $(0,015)$ \\
\hline \multirow[t]{2}{*}{ LUZAK $_{\mathrm{ij}}$} & $-0,045^{* * *}$ & $-0,046^{* * *}$ & $-0,028^{* *}$ & $-0,180^{* * *}$ & $-0,199^{* * *}$ & $-0,096^{* * *}$ & $-0,029^{* * *}$ \\
\hline & $(0,004)$ & $(0,004)$ & $(0,012)$ & $(0,019)$ & $(0,037)$ & $(0,006)$ & $(0,006)$ \\
\hline \multirow[t]{2}{*}{$\mathrm{LBS}_{\text {it }}$} & $-0,106^{*}$ & $-1,627^{* * *}$ & $0,751^{* * *}$ & $1,075^{* * *}$ & $-0,081$ & $0,167^{*}$ & $-0,503^{* * *}$ \\
\hline & $(0,063)$ & $(0,094)$ & $(0,123)$ & $(0,313)$ & $(0,495)$ & $(0,089)$ & $(0,090)$ \\
\hline \multirow[t]{2}{*}{$\mathrm{LS}_{\text {ist }}$} & $0,016^{* * *}$ & $0,046^{* * *}$ & 0,003 & $0,112^{* * *}$ & 0,036 & $0,039^{* * *}$ & $0,037^{* * *}$ \\
\hline & $(0,002)$ & $(0,003)$ & $(0,004)$ & $(0,014)$ & $(0,035)$ & $(0,005)$ & $(0,003)$ \\
\hline \multirow{2}{*}{$\mathrm{BTA}_{\mathrm{ijt}}$} & $0,021^{* * *}$ & $0,036^{* * *}$ & $-0,030^{* * *}$ & $0,068^{* * *}$ & $-0,013$ & $0,052^{* * *}$ & 0,010 \\
\hline & $(0,006)$ & $(0,007)$ & $(0,011)$ & $(0,025)$ & $(0,035)$ & $(0,009)$ & $(0,007)$ \\
\hline \multirow[t]{2}{*}{$\mathrm{LTM}_{\mathrm{ijt}}$} & $-0,224^{* * *}$ & $-0,224^{* * *}$ & $-0,336^{* * *}$ & $-0,484^{* * *}$ & $-0,620^{* * *}$ & $-0,430^{* * *}$ & $-0,168^{* * *}$ \\
\hline & $(0,007)$ & $(0,007)$ & $(0,021)$ & $(0,033)$ & $(0,058)$ & $(0,012)$ & $(0,009)$ \\
\hline \multirow[t]{2}{*}{$\mathrm{LGS}_{\text {it }}$} & 0,001 & $0,008^{* * *}$ & $-0,049^{* * *}$ & $0,027^{* * *}$ & 0,006 & $0,021^{* * *}$ & $-0,016^{* * *}$ \\
\hline & $(0,001)$ & $(0,001)$ & $(0,008)$ & $(0,007)$ & $(0,011)$ & $(0,001)$ & $(0,002)$ \\
\hline \multirow[t]{2}{*}{$\mathrm{LP}_{\text {it }}$} & $0,029^{* * *}$ & $0,014^{* * *}$ & $0,059^{* * *}$ & $-0,076^{* * *}$ & 0,018 & 0,00002 & $0,049^{* * *}$ \\
\hline & $(0,002)$ & $(0,003)$ & $(0,007)$ & $(0,014)$ & $(0,025)$ & $(0,004)$ & $(0,003)$ \\
\hline \multirow[t]{2}{*}{$\alpha$} & 0,695 & $3,853^{* * *}$ & $12,69^{* * *}$ & $-2,047$ & $-1,624$ & $-2,623^{* * *}$ & $2,109^{* * *}$ \\
\hline & $(0,495)$ & $(0,635)$ & $(1,495)$ & $(2,472)$ & $(4,296)$ & $(0,708)$ & $(0,689)$ \\
\hline$N$ & 977.334 & 794.769 & 182.565 & 54.156 & 19.266 & 357.494 & 546.418 \\
\hline$R^{2}$ & 0,939 & 0,940 & 0,940 & 0,907 & 0,914 & 0,929 & 0,946 \\
\hline $\begin{array}{l}\text { Hausman: } \\
\text { chi2(9) }\end{array}$ & $144.688,64^{* * *}$ & $94.553,41^{* * *}$ & $28.911,10^{* * *}$ & $12.178,25 * * *$ & $3.119,57^{* * *}$ & $13.939,38^{* * *}$ & $77.831,49^{* * *}$ \\
\hline
\end{tabular}

Modelde yer alan kontrol değişkenlerinden ihracatçı ülkenin gelir düzeyinin $\left(\mathrm{LGSYIH}_{\mathrm{it}}\right)$, etkisi, temel modelde pozitif; fakat istatistiksel olarak anlamlı değildir. Gelir düzeyine bağlı olarak yapılan ayrıştırma sonucuna göre, ihracatçı ülkenin gelir düzeyi $\left(\mathrm{LGSYIH}_{\mathrm{it}}\right)$ ile yerli katma değer $\left(\mathrm{LYKD}_{\mathrm{ijst}}\right)$ arasında istatistiksel olarak anlamlı ve negatif bir ilişki bulunmaktadır. Elde edilen bu sonuç, Kowalski (2015) tarafından vurgulandığı üzere; piyasa büyüklüğünün geri bağ katılımını artırması ile ilişkilidir. Endüstri düzeyindeki modeller, imalat sanayi endüstrisinde ihracatçı ülkenin gelir düzeyindeki artışın $\left(\mathrm{LGSYIIH}_{\mathrm{it}}\right)$, yerli katma değeri $\left(\mathrm{LYKD}_{\mathrm{ijst}}\right)$ artırdı̆̆ını göstermektedir. Elde edilen bu sonuca benzer bulgular elde eden Vrh (2018), Avrupa Birliği (AB) eski ve yeni üye ülkelerinin geliri ile yerli katma değer arasında pozitif bir ilişki olduğu sonucuna ulaşmıştır. Tarım, madencilik ve hizmetler endüstrisinde; ihracatçı ülkenin gelir düzeyinin $\left(\mathrm{LGSYIH}_{\mathrm{it}}\right)$, yerli katma değer $\left(\mathrm{LYKD}_{\mathrm{ijst}}\right)$ üzerinde istatistiksel olarak anlamlı bir etkisinin olmadığı sonucuna ulaşılmıştır.

İthalatçı ülkenin gelir düzeyi $\left(\mathrm{LGSYIH}_{\mathrm{jt}}\right)$ katsayısı, temel modelde, gelişmiş ülkelerde ve endüstri düzeyindeki modellerde istatistiksel olarak anlamlı ve pozitiftir. Elde edilen bu sonuç, 
ithalatçı ülkelerin gelir düzeyindeki $\left(\mathrm{LGSYIH}_{\mathrm{jt}}\right)$ artışın, yabancı katma değer kullanımını artırdığını göstermektedir.

Açıklayıcı değişkenlerden bir diğeri uzaklıktır $\left(\mathrm{LUZAK}_{\mathrm{ij}}\right)$. Uzaklık $\left(\mathrm{LUZAK}_{\mathrm{ij}}\right)$ değişkenine ait katsayılar, tüm modellerde istatistiksel olarak anlamlı ve negatiftir. Benzer şekilde LopezGonzalez (2016), uzaklığın yerli katma değeri $\left(\mathrm{LYKD}_{\mathrm{ijst}}\right)$ gelişmiş ülkelerde $\% 0,10$; yükselen ekonomilerde de \%0,19 oranında azalttığı bulgusunu elde etmiştir.

Yerli katma değer üzerindeki etkisi incelenen diğer bir değişken, beşerî sermayedir $\left(\mathrm{LBS}_{\mathrm{it}}\right)$. Analiz sonucu, gelişmekte olan ülkelere ve imalat sanayi endüstrisine ait modelde, beşerî sermayenin $\left(\mathrm{LBS}_{\mathrm{it}}\right.$ ) etkisinin istatistiksel olarak anlamlı ve pozitif olduğunu göstermektedir. Öte yandan, temel modelde, gelişmiş ülke ve hizmetler endüstrisi modelinde; beşerî sermaye $\left(\mathrm{LBS}_{\text {it }}\right)$ değişkeninin katsayısı, istatistiksel olarak anlamlı ve negatiftir. Ulaşılan sonuç, Van der Marel (2015) ve Vrh (2018)'in ulaştığı sonuçlara benzerdir. Beşerî sermayedeki artışın, yerli katma değeri $\left(\mathrm{LYKD}_{\mathrm{ijst}}\right)$ gelişmiş ülkelerde negatif; gelişmekte olan ülkelerde ise pozitif etkilemekte olduğu sonucu; gelişmiş ülkelerin eğitimde ya da beşerî sermayede doygunluğa ulaştığını; öte yandan, gelişmekte olan ülkelerin eğitimde iyileşmeye ihtiyaç duyduğunu göstermektedir. Bir diğer sebep olarak beşerî sermayesi yüksek olanların, KDZ faaliyetlerine yüksek oranda dahil olmaması gösterilebilir.

Sermaye $\left(L_{\text {it }}\right)$ değişkeninin katsayısı, temel modelde; gelişmiş ülke modelinde tarım, imalat sanayi ve hizmetler endüstrisinde istatistiksel olarak anlamlı ve pozitiftir. Elde edilen bu sonuç, Kummritz vd. (2017) ve Lopez-Gonzalez (2016)'in çalışmalarının sonuçları ile uyumludur.

Modelde yer alan açıklayıcı değişkenlerden bir diğeri olan bölgesel ticaret anlaşmaları $\left(\mathrm{BTA}_{\mathrm{ijt}}\right)$, temel modelde, gelişmiş ülke modelinde, tarım ve imalat sanayi modelinde; yerli katma değer $\left(\mathrm{LYKD}_{\mathrm{ijst}}\right)$ üzerinde pozitif ve istatistiksel olarak anlamlı bir etkiye sahiptir. Diğer taraftan gelişmekte olan ülkelerde, ticaret anlaşmalarının $\left(\mathrm{BTA}_{\mathrm{ijt}}\right)$ katsayısı, istatistiksel olarak anlamlı fakat negatiftir. Elde edilen bu sonuca benzer bulgular elde eden Johnson ve Noguera (2012b), ticaret anlaşması yapan ülkelerin ihracatlarının artarken; yerli katma değerin düştüğü sonucuna ulaşmıştır. Bu sonucun elde edilmesinde, ticaret anlaşmalarının girdi maliyetlerini azaltması sonucunda; artan ithal girdi kullanımının katma değeri düşürmesi etkilidir.

Ticaret maliyetleri ( $\mathrm{LTM}_{\mathrm{ijt}}$ ) değişkeninin katsayısı, teorik beklentiler ile uyumlu olarak tüm modellerde istatistiksel olarak anlamlı ve negatiftir. Ticaret maliyetlerinin $\left(\mathrm{LTM}_{\mathrm{ijt}}\right)$ artışı, rekabetçiliği artırmak için maliyet azaltıcı faaliyetlere yönelterek firmaların ucuz ithal girdi kullanımını artırmakta ve yerli katma değerin $\left(\mathrm{LYKD}_{\mathrm{ijst}}\right)$ düşmesine sebep olmaktadır.

Modelde yer alan açıklayıcı değişkenlerden bir diğeri olan gelen doğrudan yabancı sermaye yatırımları $\left(\mathrm{LGS}_{\mathrm{it}}\right)$ değişkeninin katsayısı, temel modelde istatistiksel olarak anlamlı değildir. Analizde ulaşılan bulgu ile uyumlu olarak Kummritz vd. (2017), gelen doğrudan yabancı sermaye yatırımlarının, yerli katma değeri $\left(\mathrm{LYKD}_{\mathrm{ijst}}\right)$ etkilemediği sonucuna ulaşmıştır. Öte yandan, gelişmiş ülke modelinde ve imalat sanayi için gerçekleştirilen modelde, doğrudan yabancı sermaye yatırımlarının $\left(\mathrm{LGS}_{\mathrm{it}}\right)$, yerli katma değeri $\left(\mathrm{LYKD}_{\mathrm{ijst}}\right)$ artırdığı sonucuna ulaşılmıştır. Ulaşılan sonuç, Lopez-Gonzalez (2016)'in bulgularına benzerdir. Gelişmekte olan ülkeler ve hizmetler endüstrisi için gerçekleştirilen analiz sonuçları, doğrudan yabancı sermaye yatırımlarının $\left(\mathrm{LGS}_{\mathrm{it}}\right)$ istatistiksel olarak anlamlı ve negatif işaretli olduğunu göstermektedir. 
Teknolojik ilerleme ve yeniliğin bir temcilcisi olarak modele eklenen patent başvuruları $\left(L P_{i t}\right)$ değişkeninin etkisi, temel model, gelişmiş ve gelişmekte olan ülke modeli ve hizmetler endüstrisi için oluşturulan modelde, istatistiksel olarak anlamlı ve pozitiftir. Bu sonuç, Caraballo ve Jiang (2016) ve Vrh (2018)'in bulguları ile uyumludur. Bilgi temelli sermayenin temini ile ülkelerin rekabetçilikleri artmış ve katma değer oranında artış meydana gelmiştir.

\subsubsection{Yabancı Katma Değerin İleri Bağ Katılımı Üzerindeki Etkisi}

Tablo 2'de temel model ve ülke ve endüstri düzeyindeki model sonuçları yer almaktadır. Temel model ve ülke ve endüstri düzeyinde yapılan model sonuçları, yabancı katma değerin $\left(\mathrm{LYAB}_{\mathrm{ijst}-1}\right)$, ileri bağ katılımını $\left(\mathrm{LIBKK}_{\mathrm{ijst}}\right)$ artırdığını göstermektedir. Endüstri düzeyindeki model sonuçlarına göre; yabancı katma değerin $\left(\mathrm{LYAB}_{\mathrm{ijst}-1}\right)$, ileri bağ katılımı ( $\left.\mathrm{LIBK}_{\mathrm{ijst}}\right)$ üzerindeki etkisinin en yüksek olduğu endüstri, hizmetlerdir.

Modelde yer alan kontrol değişkenlerinden olan ihracatçı ülkenin gelir düzeyine $\left(\mathrm{LGSYIH}_{\mathrm{it}}\right.$ ) ait katsayı, temel modelde, pozitif ve istatistiksel olarak anlamlıdır. Piyasa büyüklüğü arttıkça bu ülkelere ait girdilerin, diğer ülkelerin ihracatları için kullanılma oranı artmıştır. Ulaşılan sonuç, Yameogo ve Jammeh (2019), Mouanda ve Gong (2019) ve Kowalski vd. (2015)'nin sonuçları ile uyumludur. Gelir düzeyine bağlı olarak gerçekleştirilen analiz sonucunda, gelişmiş ülkelerin gelir düzeyi $\left(\mathrm{LGSYIH}_{\mathrm{it}}\right)$ ile ileri bağ katılımı $\left(\mathrm{LIBK}_{\mathrm{ijst}}\right)$ arasında istatistiksel olarak anlamlı bir ilişki olmadığı bulgusu elde edilmiştir. Gelişmekte olan ülkelerin gelir düzeyi $\left(\mathrm{LGSYIH}_{\mathrm{it}}\right)$ ile ileri bağ katılımı $\left(\mathrm{LIBK}_{\mathrm{ijst}}\right)$ arasında istatistiksel olarak anlamlı ve negatif bir ilişkinin olduğu sonucuna ulaşıımıştır. Endüstri düzeyinde yapılan model sonuçları, imalat sanayi endüstrisinde ihracatçı ülkenin gelir düzeyi $\left(\mathrm{LGSYİH}_{\mathrm{it}}\right)$ ile ileri bağ katılımı $\left(\mathrm{LIBK}_{\mathrm{ijst}}\right.$ ) arasında istatistiksel olarak anlamlı ve pozitif bir ilişkinin olduğunu göstermektedir. Diğer endüstrilerde ise iki değişken arasında istatistiksel olarak anlamlı bir ilişkinin olmadığı bulgusu elde edilmiştir.

Ithalatçı ülkenin gelir düzeyi ( $\mathrm{LGSYIH}_{\mathrm{jt}}$ ) değişkenine ait katsayı, temel modelde, gelişmiş ve gelişmekte olan ülke ve hizmetler endüstrisi modellerinde istatistiksel olarak anlamlı ve negatiftir. İthalatçı ülkenin piyasa büyüklüğü $\left(\mathrm{LGSYIH}_{\mathrm{jt}}\right)$ ile ithal girdi kullanımı, negatif ilişkili olduğundan; ithalatçı ülkenin gelir katsayısının negatif işaretli olması beklentilerle uyumludur.

Modelde yer alan uzaklık (LUZAK ${ }_{\mathrm{ij}}$ ) değişkeninin katsayısı teorik beklentilere uygun olarak, temel modelde negatif işaretli ve istatistiksel olarak anlamlıdır. Gelişmiş ülkelerde ve hizmetler endüstrisi dışındaki tüm endüstrilerde, uzaklığın $\left(\mathrm{LUZAK}_{\mathrm{ij}}\right)$, ileri bağ katılımını $\left(\mathrm{LIBK}_{\mathrm{ijst}}\right)$ düşürdüğü sonucuna ulaşılmıştır. Elde edilen sonuç, Yameogo ve Jammeh (2019)'in çalışmasının bulguları ile uyumludur.

Beşerî sermaye $\left(\mathrm{LBS}_{\mathrm{it}}\right)$ değişkenine ait katsayı, temel modelde teorik beklentiler ile uyumlu olarak istatistiksel olarak anlamlı ve pozitiftir. Benzer şekilde, gelişmekte olan ülkeler için ve tarım ve imalat sanayi endüstrisi için gerçekleştirilen analizde de beşerî sermayenin $\left(\mathrm{LBS}_{\text {it }}\right)$ etkisinin istatistiksel olarak anlamlı ve pozitif işaretli olduğu sonucuna ulaşılmıştır. Ulaşılan sonuç, Yameogo ve Jammeh (2019) ve Fernandes vd. (2020)'nin çalışmalarının sonuçları ile uyumludur. Öte yandan, gelişmiş ülkelerde beşerî sermayenin $\left(\mathrm{LBS}_{\text {it }}\right)$ işareti negatiftir. İşaretin negatif olmasının sebebi, yerli katma değer modellerinde de ifade edildiği üzere, gelişmiş ülkelerin eğitimde ya da beşerî sermayede doygunluğa ulaşması ya da beşerî sermayesi yüksek olanların KDZ faaliyetlerine yüksek oranda dahil olmamasıdır. 
Tablo 2: Yabancı Katma Değerin İleri Bağ Katılımı Üzerindeki Etkisi

\begin{tabular}{|c|c|c|c|c|c|c|c|}
\hline & $\begin{array}{l}\text { Temel } \\
\text { Model }\end{array}$ & $\begin{array}{l}\text { Gelişmiş } \\
\text { Ülke }\end{array}$ & $\begin{array}{l}\text { Gelişmekte } \\
\text { Olan Ülke }\end{array}$ & Tarım & Madencilik & $\begin{array}{l}\text { Imalat } \\
\text { Sanayi }\end{array}$ & Hizmetler \\
\hline \multirow[t]{2}{*}{$\mathrm{LYAB}_{\mathrm{ijst}-1}$} & $0,878^{* * *}$ & $0,865^{* * *}$ & $0,892^{* * *}$ & $0,718^{* * *}$ & $0,804^{* * *}$ & $0,739^{* * *}$ & $0,910^{* * *}$ \\
\hline & $(0,002)$ & $(0,002)$ & $(0,004)$ & $(0,008)$ & $(0,013)$ & $(0,004)$ & $(0,002)$ \\
\hline \multirow[t]{2}{*}{ LGSYİH $_{\text {it }}$} & $0,096^{* * *}$ & $-0,002$ & $-0,207^{* * *}$ & $-0,132$ & 0,0602 & $0,155^{* * *}$ & 0,045 \\
\hline & $(0,022)$ & $(0,028)$ & $(0,067)$ & $(0,140)$ & $(0,151)$ & $(0,033)$ & $(0,028)$ \\
\hline \multirow[t]{2}{*}{ LGSYİH $_{j t}$} & $-0,135^{* * *}$ & $-0,102^{* * *}$ & $-0,201^{* * *}$ & 0,081 & $-0,170$ & $-0,011$ & $-0,111^{* * *}$ \\
\hline & $(0,017)$ & $(0,019)$ & $(0,044)$ & $(0,097)$ & $(0,133)$ & $(0,027)$ & $(0,022)$ \\
\hline \multirow[t]{2}{*}{ LUZAK $_{\mathrm{ij}}$} & $-0,022^{* * *}$ & $-0,023^{* * *}$ & 0,022 & $-0,187^{* * *}$ & $-0,173^{* * *}$ & $-0,120^{* * *}$ & 0,006 \\
\hline & $(0,008)$ & $(0,008)$ & $(0,022)$ & $(0,042)$ & $(0,046)$ & $(0,012)$ & $(0,009)$ \\
\hline \multirow[t]{2}{*}{$\mathrm{LBS}_{\mathrm{it}}$} & $0,261^{* *}$ & $-1,204^{* * *}$ & $1,165^{* * *}$ & $1,735^{* * *}$ & $-0,556$ & $0,388^{* *}$ & $-0,101$ \\
\hline & $(0,102)$ & $(0,141)$ & $(0,193)$ & $(0,507)$ & $(0,676)$ & $(0,157)$ & $(0,137)$ \\
\hline \multirow[t]{2}{*}{$\mathrm{LS}_{\text {ist }}$} & $0,039^{* * *}$ & $0,057^{* * *}$ & $0,055^{* * *}$ & $0,243^{* * *}$ & $0,076^{*}$ & $0,079^{* * *}$ & $0,054^{* * *}$ \\
\hline & $(0,004)$ & $(0,005)$ & $(0,007)$ & $(0,032)$ & $(0,040)$ & $(0,009)$ & $(0,005)$ \\
\hline \multirow[t]{2}{*}{$\mathrm{BTA}_{\mathrm{ijt}}$} & $-0,007$ & 0,002 & $-0,064^{* * *}$ & 0,006 & $-0,038$ & $0,050^{* * *}$ & $-0,026^{* *}$ \\
\hline & $(0,010)$ & $(0,012)$ & $(0,019)$ & $(0,051)$ & $(0,050)$ & $(0,016)$ & $(0,013)$ \\
\hline \multirow[t]{2}{*}{ LTM $_{\mathrm{ijt}}$} & $-0,348^{* * *}$ & $-0,323^{* * *}$ & $-0,609^{* * *}$ & $-0,881^{* * *}$ & $-0,715^{* * *}$ & $-0,652^{* * *}$ & $-0,264^{* * *}$ \\
\hline & $(0,013)$ & $(0,013)$ & $(0,038)$ & $(0,069)$ & $(0,076)$ & $(0,020)$ & $(0,015)$ \\
\hline \multirow[t]{2}{*}{$\mathrm{LGS}_{\mathrm{it}}$} & $-0,004^{* * *}$ & $0,002^{*}$ & $-0,042^{* * *}$ & 0,009 & 0,012 & $0,013^{* * *}$ & $-0,019^{* * *}$ \\
\hline & $(0,001)$ & $(0,001)$ & $(0,008)$ & $(0,009)$ & $(0,013)$ & $(0,002)$ & $(0,002)$ \\
\hline \multirow[t]{2}{*}{$\mathrm{LP}_{\mathrm{it}}$} & $0,038^{* * *}$ & $0,018^{* * *}$ & $0,099^{* * *}$ & $-0,155^{* * *}$ & 0,031 & 0,009 & $0,062^{* * *}$ \\
\hline & $(0,003)$ & $(0,003)$ & $(0,009)$ & $(0,020)$ & $(0,030)$ & $(0,006)$ & $(0,004)$ \\
\hline \multirow[t]{2}{*}{$\alpha$} & 1,226 & $4,381^{* * *}$ & $13,26^{* * *}$ & 4,986 & $9,584^{*}$ & $-2,420^{* *}$ & $2,004^{* *}$ \\
\hline & $(0,765)$ & $(0,957)$ & $(2,216)$ & $(4,563)$ & $(5,465)$ & $(1,145)$ & $(0,998)$ \\
\hline$N$ & 976.661 & 794.674 & 181.987 & 54.151 & 19.266 & 357.494 & 545.750 \\
\hline$R^{2}$ & 0,901 & 0,903 & 0,900 & 0,831 & 0,899 & 0,883 & 0,919 \\
\hline $\begin{array}{l}\text { Hausman: } \\
\text { chi2(9) }\end{array}$ & $47.474,23 * * *$ & $35.016,5^{* * *}$ & $17.271,76^{* * *}$ & $314,18^{* * *}$ & $2.092,39 * * *$ & $17.464,08^{* * *}$ & $28.597,6^{* * *}$ \\
\hline
\end{tabular}

Sermaye değişkenine ( $\left.L S_{\text {ist }}\right)$ ait katsayı, temel modelde ve diğer modellerde istatistiksel olarak anlamlı ve pozitiftir.

Tüm örnekleme ait temel modelde ve gelişmiş ülkelere ait temel modelde, bölgesel ticaret anlaşmaları $\left(\mathrm{BTA}_{\mathrm{ijt}}\right)$ ile ileri katılım arasında istatistiksel olarak anlamlı bir ilişki bulunmamaktadır. Benzer şekilde, Kowalski vd. (2015), ticaret anlaşmaları çerçevesinde gerçekleşen ithalat ve ihracatın, ileri bağ katılımını $\left(\mathrm{LIBHK}_{\mathrm{ijst}}\right)$ etkilemediği sonucununa ulaşmıştır. Öte yandan, gelişmekte olan ülkelere ait modelde ve hizmetler endüstrisi için oluşturulan modelde bölgesel ticaret anlaşmalarının $\left(\mathrm{BTA}_{\mathrm{ijt}}\right)$ katsayısı istatistiksel olarak anlamlı ve negatiftir. İmalat sanayi endüstrisinde ise bölgesel ticaret anlaşmalarının $\left(\mathrm{BTA}_{\mathrm{ijt}}\right)$, ileri bağ katılımı $\left(\mathrm{LİK}_{\mathrm{ijst}}\right)$ üzerinde istatistiksel olarak anlamlı ve pozitif bir etkisi bulunmaktadır.

Ticaret maliyetleri $\left(\mathrm{LTM}_{\mathrm{ijt}}\right)$ değişkeninin katsayısı, temel modelde ve diğer modellerde istatistiksel olarak anlamlı ve negatif işaretlidir. Ülkelerin, KDZ katılımına dahil olmalarının önemli bir sebebi, üretim maliyetlerini azaltmaktır. Ticaret maliyetlerinin arttığı bir durumda, ihracatçı ülkeye ait girdilerin, ithalatçı ülkeler tarafından ithal girdi olarak kullanımı azalacaktır. Bu sebeple elde edilen sonuç, teorik beklentiler ile uyumludur. 
Gelen doğrudan yabancı sermaye yatırımlarının $\left(\mathrm{LGS}_{\text {it }}\right)$ etkisi, temel modelde, gelişmekte olan ülkeler ve hizmetler endüstrisi için oluşturulan modelde, istatistiksel olarak anlamlı ve negatiftir. Elde edilen bu sonuç, yabancı sermayenin, yatırım yapılan ülkeye katma değer ihracatı için kaynak sağlamadığını göstermektedir. Aksine, yatırımcı firmanın gelişmiş teknoloji kullanarak düşük marjinal maliyet ile üretim yapması ve rekabeti artırması, yerli firmaların piyasa paylarının azalmasına yol açarak bu firmaları olumsuz etkilemiştir. Ülke düzeyindeki analiz sonucunda, gelişmiş ülkelerde; endüstri düzeyindeki analiz sonucunda, imalat sanayi endüstrisinde, doğrudan yabancı sermayenin $\left(L_{G S}\right.$ it $)$, ileri bağ katılımını $\left(L^{\prime} \dot{B K}_{\mathrm{ijst}}\right)$ artırdığı sonucuna ulaşılmıştır.

Teorik beklentiler ile uyumlu olarak patent başvuruları $\left(\mathrm{LP}_{\mathrm{it}}\right)$; temel modelde, gelişmiş ve gelişmekte olan ülkeler ve hizmetler endüstrisi için oluşturulan modelde, ileri bağ katılımını ( LIBKK $_{\mathrm{ijst}}$ ) artırmaktadır. Elde edilen analiz sonucu, Jona-Lasinio vd. (2016) çalışmasının sonucu ile uyumludur. Dolayısıyla, OECD (2013) Raporu'nda da yer verildiği üzere, Ar-Ge gibi alanlarda yatırımı ve bilgi temelli sermayesi yüksek olan ya da yatırım ve bilgi temelli sermayesini artıran ülkeler, daha yüksek katma değer elde etmektedir.

\subsection{Sağlamlılık Analizi}

Tüm örneklemin yer aldığı temel model analiz sonuçlarına göre yabancı katma değer $\left(\mathrm{LYAB}_{\mathrm{ijst}-1}\right)$, yerli katma değeri $\left(\mathrm{LYKD}_{\mathrm{ijst}}\right)$ ve ileri bağ katılımını ( LİBK $\left._{\mathrm{ijst}}\right)$ artırmaktadır. Ulaşılan bu sonuçların tutarlı olup olmadığını araştırmak için sağlamlılık analizi yapılmaktadır. Sağlamlıık analizinde ilk olarak, dinamik panel veri tahmin yöntemlerinden olan Genelleştirilmiş Momentler Metodu (GMM) kullanılmıştır. Sağlamlılık analizinde ikinci olarak, ülke ve endüstriye bağlı olarak kümelenmiş dirençli standart hatalar yerine; ülke, endüstri ve yıla bağı olarak kümelenmiş dirençli standart hata kullanılarak analiz gerçekleştirilmektedir. Üçüncü olarak, kukla değişkenlerinde değişiklik yapılmaktadır. Sağlamlılık analizinde dördüncü olarak, ticaret ortakları arasında ticaretin gerçekleştirilmediği gözlemlerin varlığında daha tutarlı sonuçlar veren Poisson Pseudo En Çok Olabilirlik (PPML) yöntemi kullanılmaktadır. PPML yönteminde elde edilen katsayıların yorumlaması, EKK yönteminde olduğu gibidir; fakat farklı olarak PPML yönteminde, bağımlı değişkenin logaritması alınmamaktadır. Açıklayıcı değişkenlerin ise benzer şekilde logaritması alınarak analiz gerçekleştirilmektedir.

Arellano ve Bover/ Blundell ve Bond tahmincisi kullanılarak gerçekleştirilen sistem GMM analiz sonuçlarına göre, yabancı katma değer $\left(\mathrm{LYAB}_{\mathrm{ijst}-1}\right)$, Tablo 1 ve Tablo 2'de yer alan temel model sonuçlarına benzer şekilde, yerli katma değeri $\left(\mathrm{LYKD}_{\mathrm{ijst}}\right)$ ve ileri bağ katılımını $\left(\mathrm{LIBK}_{\mathrm{ijst}}\right)$ artırmaktadır. Ülke, endüstri ve yıla bağı olarak kümelenmiş dirençli standart hata kullanılarak yapılan analiz sonuçları, yabancı katma değerin $\left(\mathrm{LYAB}_{\mathrm{ijst}-1}\right)$ istatistiksel olarak anlamlı ve pozitif işaretli olduğunu göstermektedir. Kukla değişkenlerinde değişikliğe gidilerek gerçekleştirilen üçüncü sağlamlılık analizi için dört ayrı model oluşturulmaktadır ${ }^{14}$. Model sonuçları, yabancı katma değerin $\left(\mathrm{LYAB}_{\mathrm{ijst}-1}\right)$, istatistiksel olarak anlamlı ve pozitif işaretli olduğunu göstermektedir. Yabancı katma değer katsayısı $\left(\mathrm{LYAB}_{\mathrm{ijst}-1}\right)$, Tablo 1 ve Tablo 2'nin temel modelinde elde edilen katsayılara benzerdir. PPML yöntemi kullanılarak gerçekleştirilen analiz sonuçları, yabancı katma değerin $\left(\mathrm{LYAB}_{\mathrm{ijst}-1}\right)$ katsayısının istatistiksel olarak anlamlı ve

\footnotetext{
14 ilk modelde ihracatçı ülke*ithalatçı ülke, endüstri ve yıl kuklaları kullanılmaktadır. İkinci modelde, ihracatçı ülke*endüstri, ihracatçı ülke*yıl, endüstri*yıl, ithalatçı ülke kuklaları kullanılmaktadır. Üçüncü modelde, ihracatçı ülke*ithalatçı ülke, endüstri*yıl kuklaları kullanılarak analiz gerçekleştirilmektedir. Dördüncü modelde, ihracatçı ülke, ithalatçı ülke ve endüstri*yıl kuklaları yer almaktadır.
} 
pozitif işaretli olduğunu göstermektedir. íki ayrı modelde de yabancı katma değer ( $\left.\mathrm{LYAB}_{\mathrm{ijst}-1}\right)$ katsayısı, Tablo 1 ve Tablo 2'nin temel modelinde elde edilen katsayılara benzerdir ${ }^{15}$.

\section{Sonuç}

Tezin amacı, 42 ülkenin 2000-2014 yıllarındaki KDZ katılımlarının ölçülmesi ve yabancı katma değerin yerli katma değer bağlamında ihracat performansı üzerindeki etkisinin incelenmesidir. İili ticaret verilerine dayalı olan ve Wang vd. (2013) tarafından geliştirilen ayrıştırma yönteminden yararlanılarak hesaplanan yabancı katma değerin ihracat performansı üzerindeki etkisi, diğer çalışmalardan farklı olarak LSDV yöntemi ile incelenmektedir. Tezin katkısı, betimsel ve ampirik analiz sonuçlarına bağlı olarak gelişmiş ve gelişmekte olan ülkelere özgü politikaların önerilmesidir.

Analizin ilk adımını oluşturan betimsel analiz sonuçları, 2000-2014 döneminde gelişmiş ve gelişmekte olan ülkelerin yerli katma değer oranının azaldığını; ileri katılım ve yabancı katma değer oranının arttığını göstermektedir. Elde edilen bulgulara göre, daha az yabancı katma değer ve daha yüksek ileri katılım bileşenli ihracat gerçekleştirme bağlamında, gelişmiş ülkeler, KDZ katılımından gelişmekte olan ülkelere göre daha çok fayda sağlamaktadır. Düşük teknolojili ve yoğun emek içeren üretim aşamalarında uzmanlaşan gelişmekte olan ülkeler, geri bağ katılımı ile ithal girdi temin etmekte ve gelişmiş ülkelerden bilgi ve teknoloji sağlama noktasında KDZ katılımından yararlanmaktadır.

Ampirik analizde yabancı katma değer ile yerli katma değer ve ileri katılım arasındaki ilişki incelenmektedir. Ampirik analiz bulgularına göre; yabancı katma değer, ileri katılım ve yerli katma değer bağlamında ihracat performansını artırmaktadır. İthal girdi ile yurtiçine verimli kaynak, bilgi ve teknoloji akımı gerçekleşmektedir. Firmaların kaliteli ve ucuz girdi temini ile maliyetleri azalmakta ve rekabetçilikleri artmaktadır. Gelişmiş teknoloji akımı gerçekleşen ülkelerde, nitelikli işgücüne talep artacağından, işgücü piyasasında dönüşümün sağlanması kaçınılmaz olmaktadır. İşücü piyasasında gerçekleşecek olan dönüşüm, ithal girdilerin yurtiçinde üretilmesini sağlayabilecektir.

Elde edilen tüm bu bulgular, ülkelerin KDZ katılımından farklı düzeyde fayda elde ettiğini; farklı maliyet ve risklere maruz kaldığını göstermektedir. KDZ'de yaratılan katma değerden en büyük payı, teknolojik gelişme ve yenilik süreçlerine yön veren gelişmiş ülkeler almaktadır. KDZ katılımı sonucunda gelişmiş ülkelerden yeni teknoloji ve üretim tekniklerinin temin edilmesi ile gelişmekte olan ülkeler, yurtiçi üretim arz zinciri oluşturmadan belirli bir üretim aşamasında uzmanlaşmaktadır (Rodrik, 2018). Yüksek katma değerli üretim aşamalarını gerçekleştirebilir düzeye erişmeden, küresel değer zincirine katılan gelişmekte olan ülkelerin, yerli katma değeri azalmakta ve ithal girdi bağımlılığı artmaktadır. Yüksek katma değerli yeni mal üretimine geçilmesi, düşük katma değerli üretim aşamalarının değerinin düşmesi ile gelişmekte olan ülkeler, küresel üretim düzenine ayak uyduramamakta ve rekabetçi üstünlükleri azalmaktadır.

Düşük katma değerli ve düşük teknolojili üretim gerçekleştiren, yerli katma değeri azalan ve ithal girdi bağımlılı̆̆ı artan gelişmekte olan ülkelerin, temel girdilerin yurtiçinde üretilmesinin önü açılarak, katma değeri artırma ve ithal girdi bağımlılığını azaltmaya yönelik bir politika izlemesi gerekmektedir. Küresel değer zincirinden elde edilen katma değerin artması için ülkeler, öncelikle karşılaştırmalı üstünlük sağladıkları ve verimliliklerinin daha

\footnotetext{
15 Sağlamlılık analiz sonuçları, yazarlardan istenildiği takdirde paylaşılabilecektir.
} 
yüksek olduğu endüstrilerde faaliyetlerini yürütmelidir. Gelişmiş ülkeler tarafından geliştirilen bilgi ve teknolojiden, yeni teknoloji ve üretim tekniklerinin geliştirilmesi alanında yararlanılması halinde KDZ katılımından daha yüksek fayda elde edilecektir. Yeni teknoloji ve üretim tekniklerinin geliştirilmesi için fiziki ve beşerî sermaye yatırımları yapılarak üretken ve yenilikçi kapasite oluşturulmalıdır. Bu bağlamda, Ar-Ge politikaları ve bilim, teknoloji ve yenilik politikalarını barındıran eğitim politikaları yürütülmelidir. Firmaların ve işgücünün, bilgi ve teknolojiden elde edebileceği fayda düzeyi, işgücünün niteliğine bağlı olduğundan; mevcut işgücünün beşerî sermayesini artıran iş yaşamına yönelik eğitimler düzenlenmelidir. Eğitim ve Ar-Ge politikaları ile mal ve hizmetler piyasasında yüksek katma değerli üretim ve rekabet artacaktır.

Sonuç olarak KDZ katılımı, yenilik ve teknoloji sürecine yön veren gelişmiş ülkelerin yüksek katma değerli üretim yapmasına katkıda bulunmaktadır. Gelişmekte olan ülkeler, geri endüstri bağa dayalı KDZ katılımı ile gelişmiş ülkelerden ucuz ithal girdi, gelişmiş bilgi ve teknoloji temin etme bağlamında fayda sağlamaktadır. KDZ katılımından ağırlıklı olarak geri bağ bağlamında faydalanan gelişmekte olan ülkelerin ileri bağ katılımlarını artırmaları gerekmektedir. İleri bağ katılımının artması için Ar-Ge yatırımları aracılığıyla üretimde yenilik ve teknolojiyi teşvik etmeye yönelik sanayi politikası benimsenmeli; üretken ve yenilikçi kapasite oluşturmak ve mevcut işgücünün beşerî sermayesini artırmak için nitelikli eğitim politikaları yürütülmelidir. Ar-Ge yatırımları ve beşerî sermayeyi artırıcı eğitim politikaları sonucunda yeni teknoloji ve üretim tekniklerinin geliştirilmesi ile daha yüksek katma değerli süreçlerde rekabetçilik elde edilebilecektir. 


\section{Kaynakça}

Amador, J. ve Cabral, S. (2016), "Global value chains: A survey of drivers and measures"., Journal of Economic Surveys, 30(2): 278-301.

Anderson, J. E. (1979), "A theoretical foundation for the gravity equation", The American economic review, 69(1): 106-116.

Anderson, J. E. ve Van Wincoop, E. (2003), "Gravity with gravitas: A solution to the border puzzle", American economic review, 93(1): 170-192.

Aristei, D., Castellani, D. ve Franco, C. (2013), "Firms' exporting and importing activities: is there a two-way relationship? ", Review of World Economics, 149(1): 55-84.

Assamoi, G. R., Wang, S., Gnangoin, Y. T. B. ve Edjoukou, A. J. R. (2019), "Foreign Inputs and Changes in Domestic Value Added Exports: Empirical Evidence from Latin American Countries", International Journal of Economics and Financial Issues, 9(3): 244.

Baltagi, B. (2008), Econometric analysis of panel data, John Wiley \& Sons, England.

Baldwin, R. (2013), "Trade and industrialization after globalization's second unbundling: How building and joining a supply chain are different and why it matters ", R. C., Feenstra and A. M. Taylor (Ed.), Globalization in an age of crisis: Multilateral economic cooperation in the twenty-first century, University of Chicago Press, Chicago: 165-212.

Baldwin, R. ve Lopez-Gonzalez, J. (2015), "Supply-chain trade: A portrait of global patterns and several testable hypotheses", The World Economy, 38(11): 1682-1721.

Banga, K. (2016), "Impact of global value chains on employment in India", Journal of Economic Integration: 631-673.

Bas, M. ve Strauss-Kahn, V. (2014), "Does importing more inputs raise exports? Firm-level evidence from France", Review of World Economics, 150(2): 241-275.

Caraballo, J. G. ve Jiang, X. (2016), "Value-added erosion in global value chains: an empirical assessment", Journal of Economic Issues, 50(1): 288-296.

Constantinescu, C., Mattoo, A. ve Ruta, M. (2017), Does vertical specialization increase productivity?, Policy Research Working Paper. World Bank, Washington DC: 1-15.

Daudin, G., Rifflart, C. ve Schweisguth, D. (2011), "Who produces for whom in the world economy?", Canadian Journal of Economics/Revue canadienned'économique, 44(4), 1403-1437.

Degain, C., Meng, B. ve Wang, Z. (2017), "Recent trends in global trade and global value chains. Global Value Chain Development Report 2017", Measuring and Analyzing the Impact of GVCs on Economic Development: 37-68.

Ebenstein, A., Harrison, A., McMillan, M. ve Phillips, S. (2014), "Estimating The Impact of Trade and Offshoring on American Workers Using The Current Population Surveys", The Review of Economics and Statistics: 581-595.

Evenett, S. J. ve W. Keller (2002), "On Theories Explaining the Success of the Gravity Equation, Journal of Political Economy, 110(2): 281-316.

Farole, T. ve Winkler, D. (Eds.). (2014), "Making foreign direct investment work for Sub-Saharan Africa: local spillovers and competitiveness in global value chains", The World Bank, Washington DC.

Feenstra, R. C. (1998), "Integration of trade and disintegration of production in the global economy", Journal of economic Perspectives, 12(4): 31-50.

Fernandes, A., Kee, H. L. ve Winkler, D. (2020), Determinants of Global Value Chain Participation: Cross-Country Evidence, Policy Research Working Paper No:91-97, The World Bank, Washington.

Heise, S., Pierce, J. R., Schaur, G. ve Schott, P. K. (2017), Trade Policy Uncertainty and the Structure of Supply Chains, Technical Report, Working Paper. 
Hummels, D., Ishii, J. ve Yi, K. M. (2001), "The nature and growth of vertical specialization in world trade", Journal of international Economics, 54(1): 75-96.

Johnson, R. C. ve Noguera, G. (2012a), "Accounting for intermediates: Production sharing and trade in value added", Journal of international Economics, 86(2): 224-236.

Johnson, R. C. ve Noguera, G. (2012b), Fragmentation and trade in value added over four decades, National Bureau of Economic Research. NBER No. w18186, Cambridge.

Jona-Lasinio, C. S., Manzocchi, S. ve Meliciani, V. (2016), Intangible assets and participation in global value chains: An analysis on a sample of European countries (129), LUISS Working Paper Series No:129, Rome.

Kersan-Škabić, I. (2019), "The drivers of global value chain (GVC) participation in EU member states", Economic research-Ekonomskaistraživanja, 32(1): 1204-1218.

Koopman, R., Wang, Z. ve Wei, S. J. (2014), "Tracing value-added and double counting in gross exports", American Economic Review, 104(2): 459-94.

Kowalski, P., Gonzalez, J. L., Ragoussis, A. ve Ugarte, C.(2015), Participation of Developing Countries in Global Value Chains: Implications for Trade and Trade-Related Policies (No: 179), OECD Trade Policy Papers, OECD Publishing, Paris.

Kummritz, V. (2015), Global value chains: Benefiting the domestic economy?, Graduate Institute of International and Development Studies Working Paper No. 02/2015. Graduate Institute of International and Development Studies, Geneva.

Kummritz, V., Taglioni, D. ve Winkler, D. (2017), Economic upgrading through global value chain participation: which policies increase the value added gains?, Policy Research Working Paper, The World Bank, Washington, DC, ABD.

Leontief, W. W. (1936), "Quantitative input and output relations in the economic systems of the United States", The review of economic statistics: 105-125.

Lopez-Gonzalez, J. (2016), Using foreign factors to enhance domestic export performance: A focus on Southeast Asia (No. 191), OECD Publishing, Paris.

Miroudot, S., Lanz, R. ve Ragoussis, A. (2009), Trade in intermediate goods and services, OECD Trade Policy Papers, No:93.

Mouanda-Mouanda, G. ve Gong J. (2019), " Determinants of Global Value Chains Participation for Landlocked Countries", International Journal of Social Science and Economic Research, 4: 3265-3293.

Organisation for Economic Co-operation and Development. (2013), Supporting investment in knowledge capital, growth and innovation, OECD, OECD Publishing: Paris.

Pathikonda, V., ve Farole, T. (2016), The capabilities driving participation in global value chains, The World Bank. Washington, DC, ABD.

Pierola, M. D., Fernandes, A. M. ve Farole, T. (2015), The role of imports for exporter performance in Peru, The World Bank, Washington, DC, ABD.

Rodrik, D. (2018), New Technologies, Global Value Chains, and the Developing Economies (No. 7307), CESifo Working Paper. Center for Economic Studies and Ifo Institute (CESifo), Munich.

Solaz, M. (2018), "Value added and participation in global value chains: The case of Spain", The World Economy, 41(10): 2804-2827.

Taglioni, D. and Winkler, D. (2016), Making global value chains work for development, The World Bank. Washington, DC, ABD.

Turco, A. L. ve Maggioni, D. (2013), "On the role of imports in enhancing manufacturing exports", The World Economy, 36(1): 93-120.

United Nations Conference on Trade and Development (2013), World Investment Report (Global Value Chains: Investment and Trade for Development), UNCTAD, United Nations, New York and Genova. 
United Nations Conference on Trade and Development (2018), Trade and Development Report 2018: Power, platforms and the free trade delusion, UNCTAD, United Nations, New York.

Van der Marel, E. V. D. (2015), "Positioning on the global value chain map: Where do you want to be? ", Journal of World Trade, 49(6): 915-949.

Vrh, N. (2018), "What drives the differences in domestic value added in exports between old and new EU member states?", Economic research-Ekonomskaistraživanja, 31(1): 645-663.

Wang, Z., Wei, S. J. ve Zhu, K. (2013), Quantifying international production sharing at the bilateral and sector levels, National Bureau of Economic Research, NBER No. w19677, Cambridge.

World Trade Organization (2008), World Trade Report: Trade in a Globalizing World, World Trade Organization, Geneva.

World Development Report (2020), Trading for Development in the Age of Global Value Chain, World Bank, Washington, DC.

Yameogo, N. D. ve Jammeh, K. (2019), Determinants of Participation in Manufacturing GVCs in Africa: The Role of Skills, Human Capital Endowment and Migration, The World Bank. Policy Research Working Paper No 8938, Office of the Chief Economist, Africa Region.

Ziemann, V. ve Guérard, B. (2016), Reaping the benefits of global value chains in Turkey, OECD Working Papers, OECD Publishing, Paris. 


\section{Ekler:}

Ek 1- Dünya Bankası Gayrisafi Milli Hasıla (2018) Sınıflandırmasına Göre Ülkelerin Gelişmişlik Düzeyi

\begin{tabular}{|c|c|}
\hline Gelişmiş Ülke & $\begin{array}{l}\text { Avustralya, Avusturya, Belçika, Kanada, Hırvatistan, Kıbrıs, Çekya, Danimarka, Estonya, } \\
\text { Finlandiya, Fransa, Almanya, Yunanistan, İrlanda, İtalya, Japonya, Güney Kore, Letonya, } \\
\text { Litvanya, Lüksemburg, Malta, Hollanda, Norveç, Polonya, Portekiz, Rusya, Slovakya, } \\
\text { Slovenya, İspanya, İsveç, İsviçre, Birleşik Krallık, Amerika Birleşik Devletleri }\end{array}$ \\
\hline $\begin{array}{l}\text { Gelişmekte Olan } \\
\text { Ülke }\end{array}$ & Brezilya, Bulgaristan, Çin, Macaristan, Endonezya, Meksika, Romanya, Hindistan, Türkiye \\
\hline
\end{tabular}

Ek 2-Tanımlayıcı İstatistikler

\begin{tabular}{cccccc}
\hline Değişken & Gözlem & Ortalama & S. Sapma & Min & Max \\
\hline LYKD $_{\text {ijst }}$ & 1.361 .892 & $-0,248$ & 4,056556 & $-75,07221$ & 11,30238 \\
LiBK $_{\text {ijst }}$ & 1.360 .624 & $-1,96403$ & 4,215443 & $-81,82497$ & 9,767602 \\
LYAB $_{\text {ijst }}$ & 1.361 .891 & $-2,059406$ & 4,226537 & $-77,47855$ & 10,40589 \\
LGSYİH $_{\text {it }}$ & 1.392 .606 & 26,65608 & 1,71189 & 22,64706 & 30,41335 \\
LGSYİH $_{\text {jt }}$ & 1.392 .606 & 26,65608 & 1,71189 & 22,64706 & 30,41335 \\
LUZAK $_{\text {ij }}$ & 1.394 .820 & 7,936257 & 1,107738 & 4,087945 & 9,828204 \\
LBS $_{\text {it }}$ & 1.462 .860 & 1,112343 & 0,1577721 & 0,5777764 & 1,317556 \\
$\mathbf{L S}_{\text {ist }}$ & 1.408 .344 & 6,800649 & 4,23082 & 0,2790115 & 25,28321 \\
$\mathbf{B T A}_{\mathbf{i j t}}$ & 1.462 .860 & 0,6579919 & 0.4743825 & 0 & 1 \\
$\mathbf{L T M}_{\text {ijt }}$ & 1.287 .900 & 4,75715 & 0,4955422 & 0,6630179 & 6,562526 \\
$\mathbf{L G S}_{\mathbf{i t}}$ & 1.322 .244 & 23,11692 & 1,72027 & 14,80182 & 27,37084 \\
$\mathbf{L P}_{\text {it }}$ & 1.358 .532 & 8,076442 & 2,452476 & 1,098612 & 13,74098 \\
\hline
\end{tabular}

Ek 3 Çoklu Bağlantı Test Sonucu ${ }^{16}$

\begin{tabular}{|c|c|c|c|c|c|}
\hline \multicolumn{3}{|c|}{ Yerli Katma Değer (LYKD ijst $\left._{\text {( }}\right)$} & \multicolumn{3}{|c|}{ illeri Katılım (LiBK ijst ) } \\
\hline Değişken & VIF & $1 /$ VIF & Değişken & VIF & $1 /$ VIF \\
\hline LGSYİH $_{\text {it }}$ & 8,37 & 0,119475 & LGSYİH $_{\text {it }}$ & 8,37 & 0,119420 \\
\hline $\mathbf{L} \mathbf{P}_{\mathrm{it}}$ & 8,27 & 0,120866 & $\mathrm{LP}_{\text {it }}$ & 8,28 & 0,120766 \\
\hline LUZAK $_{\mathrm{ij}}$ & 4,43 & 0,225497 & LUZAK $_{i j}$ & 4,43 & 0,225509 \\
\hline $\mathbf{L T M}_{\mathrm{ijt}}$ & 3,38 & 0,295519 & $\mathrm{LTM}_{\mathrm{ijt}}$ & 3,38 & 0,295533 \\
\hline BTA $_{\mathrm{ijt}}$ & 1,98 & 0,506301 & BTA $_{i j t}$ & 1,98 & 0,506217 \\
\hline $\mathbf{L G S}_{\text {it }}$ & 2,15 & 0,464465 & $\mathrm{LGS}_{\text {it }}$ & 2,15 & 0,464512 \\
\hline LGSYİH $_{\mathrm{jt}}$ & 1,87 & 0,534581 & LGSYİH $_{j t}$ & 1,87 & 0,534724 \\
\hline LYAB $_{\mathrm{ijst}}$ & 2,49 & 0,401555 & LYAB $_{i j s t}$ & 2,49 & 0,401190 \\
\hline $\mathbf{L S}_{\text {ist }}$ & 1,51 & 0,664074 & $\mathrm{LS}_{\text {ist }}$ & 1,51 & 0,664304 \\
\hline $\mathbf{L B S}_{\mathrm{it}}$ & 1,38 & 0,723391 & $\mathrm{LBS}_{\mathrm{it}}$ & 1,38 & 0,722907 \\
\hline Ortalama VIF & 2,13 & & Ortalama VIF & 2,13 & \\
\hline
\end{tabular}

\footnotetext{
${ }^{16}$ Endüstri ve yıl kuklalarının test sonucu tabloya eklenmemiştir.
} 


\section{Extended Summary}

\section{The Effect of the Foreign Value Added on the Domestic Value Added in Exports}

The reduction cost of international trade, improvements in information and communication technologies have changed the structure of the production of goods and services. The world production, trade and investment policies are organized around global value chains (GVCs) participation which refers to the international fragmentation of production. The production is vertically fragmented across countries; parts and components are produced in different locations and are assembled along the supply chain. The international fragmentation of production arises from technological progress, cost, access to resources and market channels. Countries participate in GVCs through backward and forward linkages. Using foreign input/value added in domestic exports defines backward linkages. Forward linkages show the domestic inputs/value added of the country contained in the exports. The importance of GVCs has been steadily increasing in the last decades. UNCTAD's 2013 World Investment report shows that about two-thirds of global trade consists of trade in intermediate goods and services.

Measuring participation in GVCs allows us to understand how countries benefit from participation in GVCs, how GVCs affect their economic performances, and what policies should be implemented to have greater benefits from participation in GVCs. Although GVCs have become an important element in economic policy, not much is known about their impact on export. The aim of this study is to examine the impact of foreign value added on domestic value added content of exports. This study also examines the role of different trade, investment and other policies on export performance. Using a least squares dummy variable (LSDV) approach, the empirical analysis is carried out using WIOD (World Input-Output Database) data for the period of 2000-2014 of 42 countries. This study covers agricultural, mining, manufacturing, and service industries.

The degree of benefits from participation in GVCs depends on how much value a country creates in GVCs. A country's comparative advantage, skills and resource endowments determine its position in the value chain. Therefore, the gains from GVC participation are not equally distributed, not only within but also between countries. To measure participation of a country in GVCs, an indicator that shows the percentage of the value added in the participation of GVCs is calculated using the decomposition method of Wang et al. (2013). The foreign and domestic value added in a country's export, and forward participation are measured in regard to the indicator. The descriptive analysis indicates that the foreign value added share in manufacturing and service industries' exports is lower in developed countries. Developed countries have higher forward participation share in exports. The domestic value added share in exports decreases, while the foreign value added and forward participation share in exports increase in the developed and developing countries between the years of 2000 and 2014. The use of foreign intermediates in developing countries' exports is higher than the use of the developing countries' intermediates in other countries' exports.

GVCs participation enables countries to increase competitiveness by accessing more sophisticated and competitively priced imported intermediates. The results suggest that foreign value added enhances the export performance in the context of forward linkage and domestic value added. Foreign value added is a complement rather than a substitute for export performance. GVCs promote the developing countries to accelerate their industralization and development by taking advantage of other countries' industrial bases. Firms in developing countries enter foreign markets at lower costs and benefit from concentrating on specific production processes or tasks by integrating in GVCs. By providing access to capital and inputs, GVCs provide efficient production and diffusion of technology. Using the high-technology in production increases the competitiveness and productivity of the countries.

Increasing usage of technology in production also has generated transformation in labor market. New production technologies increase the demand for skilled labor, promote countries to decrease labor-intensive methods in production and to use less labor-intensive products of developing countries. The results indicate that development of the human capital through education and improving the availability of innovation increases competitiveness of developing countries.

The GVCs participation of domestic firms can help developing countries accelerate their industrialization process. However, GVCs participation is a necessary but not a sufficient condition for development as GVCs allow developing countries to access to global markets by concentrating on specific production processes or tasks without building all production capacity for a product. Because developing countries have not accelerated their industrialization process, their domestic value added in exports declines; their dependence on imported inputs increases.

The analysis provides the evidence that imported intermediate inputs increase competitiveness, so countries should implement an economic policy that facilitates access to the most competitive intermediate inputs. The findings show that GVCs participation enables developed countries to concentrate on high value added production. Developing countries with low value added production obtain cheap imported inputs, advanced knowledge, and technology by means of GVCs participation. The new technologies in production decrease the labor share of income and increase the demand for skilled workers. Because the higher value added positions in GVCs require high-level technical skills, investment in education and innovative policy become even more important. Results suggest that the developing countries should implement education and investment policies in view of new technologies and production techniques so as to enable high value added production. 